\title{
Beyond High and Lonesome: A Comparative Analysis of Early Male and Contemporary Female Bluegrass Vocal Styles
}

Hillary C. Kay

Follow this and additional works at: https://researchrepository.wvu.edu/etd

\section{Recommended Citation}

Kay, Hillary C., "Beyond High and Lonesome: A Comparative Analysis of Early Male and Contemporary Female Bluegrass Vocal Styles" (2016). Graduate Theses, Dissertations, and Problem Reports. 5949. https://researchrepository.wvu.edu/etd/5949

This Thesis is protected by copyright and/or related rights. It has been brought to you by the The Research Repository @ WVU with permission from the rights-holder(s). You are free to use this Thesis in any way that is permitted by the copyright and related rights legislation that applies to your use. For other uses you must obtain permission from the rights-holder(s) directly, unless additional rights are indicated by a Creative Commons license in the record and/ or on the work itself. This Thesis has been accepted for inclusion in WVU Graduate Theses, Dissertations, and Problem Reports collection by an authorized administrator of The Research Repository @ WVU. For more information, please contact researchrepository@mail.wvu.edu. 
Beyond High and Lonesome:

A Comparative Analysis of

Early Male and Contemporary Female Bluegrass Vocal Styles

\author{
Hillary C. Kay
}

Thesis submitted

to the College of Creative Arts

at West Virginia University

in partial fulfillment of the requirements for the degree of

Master of Music in

Musicology

Travis Stimeling, Ph.D., Chair

Evan MacCarthy, Ph.D.

Andrew Kohn, Ph.D

School of Music

\title{
Morgantown, West Virginia \\ 2016
}

Copyright 2016 Hillary Kay 


\title{
ABSTRACT \\ Beyond High and Lonesome: \\ A Comparative Analysis of \\ Early Male and Recent Female Bluegrass Vocal Styles
}

\author{
Hillary C. Kay
}

This thesis is a comparative analysis of the bluegrass vocal styles of early male performers of the 1940s and 50s and contemporary female performers actively performing between 2001 and 2016. Four songs were selected from the standard bluegrass repertoire, each one having been recorded by both an early male performer and a contemporary female performer. The three body chapters of the study draw comparisons between the male performers, between the female performers, and then between the two groups. The aims of this study are to better understand 1) How bluegrass singing, which is rooted in male vocal production, is performed by female vocalists and 2) how the two groups studied engage with the lyrical content by using their voices. 


\section{Table of Contents}

Chapter 1 - Introduction $\quad 1$

$\begin{array}{ll}\text { Literature Review } & 3\end{array}$

$\begin{array}{ll}\text { Methodology } & 18\end{array}$

Chapter 2 - Analysis of Early Male Recordings 23

Chapter 3 - Analysis of Contemporary Female Recordings 39

Chapter 4 - Comparison of Early Male and Contemporary Female Recordings 53

$\begin{array}{ll}\text { Chapter } 5 \text { - Conclusion } & 65\end{array}$ 


\section{LIST OF FIGURES AND TABLES}

Figure 1. Excerpt from Patty Loveless' recording of "Working on a Building" which shows the marking for vocal scoop (m. 2), slides (mm 4-5), and vocal breaking (m. 5), ................. 21

Figure 2. Excerpt from Bill Monroe's recording of "In the Pines," showing the top of Monroe's

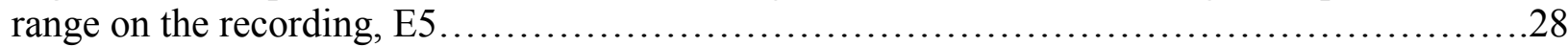

Table 1. Comparison of lyrics for the Monroe and Woodsmith recordings of "In the Pines.".... 56

Table 2. Comparison of lyrics for the Monroe and Loveless recordings of "I'm Working on a Building."

Table 3. Comparison of lyrics for the Osborne and Vincent recordings of "Bluegrass Express."

Table 4. Comparison of lyrics for the Stanley and Washburn recordings of "Pretty Polly." ...... 62 


\section{Chapter 1: Introduction}

For many years, the origin story of bluegrass music has been a one of a genre built by men. The story begins with Bill Monroe, a young musician with a striking "high and lonesome" voice and considerable skill on the mandolin, who formed his band, The Blue Grass Boys, in 1939. ${ }^{1}$ The band was a constantly-changing cast of musically-skilled characters, some more wellknown than others, but all were expected to play up to Bill Monroe's high standards. ${ }^{2}$ However, the name of Monroe's band was misleading, as not all of the Blue Grass Boys were male. Within the first three years of playing together, the band had a female member, Sally Ann Forrester, who toured and recorded with the band until 1946. ${ }^{3}$ The Blue Grass Boys later welcomed their second female member in 1952. Bessie Lee Maudlin toured and recorded on the bass with the band for twelve years, but was replaced sometime in 1964 by Monroe's son, James. ${ }^{4}$ While Forrester and Maudlin were the only two women who played regularly with the Blue Grass Boys, there were many others who had been playing country and hillbilly music long before Monroe and his band appeared on the scene in the 1930s, and many who performed in the bluegrass community after the genre was established. Unfortunately, because of societal expectations of a patriarchal culture, women were commonly expected to give up their music careers to become homemakers and mothers. Those who did perform often had to play with spouses or family bands, as unchaperoned women were frowned upon in the early decades of the $20^{\text {th }}$ Century. ${ }^{5}$ While the

\footnotetext{
${ }^{1}$ Neil Rosenberg, Bluegrass: A History (Urbana: University of Illinois Press, 2005), 42.

${ }^{2}$ Neil Rosenberg, Bluegrass, 60.

${ }^{3}$ Murphy Hicks Henry, Pretty Good for a Girl: Women in Bluegrass (Urbana: University of Illinois Press, 2013), 18.

${ }^{4}$ Henry, Pretty Good for a Girl, 52.

${ }^{5}$ Mary A. Bufwack and Robert K. Oermann, Finding Her Voice: The Saga of Women in Country Music, (New York: Crown Publishers, 1993), 48.
} 
accomplishments of these bluegrass women had been understated for years, recent scholarship and attitudes have been changing, allowing for a discussion of gender politics in the bluegrass industry, as well as a broader, more inclusive definition of the bluegrass sound, to which this study contributes.

My interest in this research was borne out of my personal experiences in performing bluegrass music. As I built my repertoire of bluegrass songs, I noted that many of them talked about women, but few of them did so from a female perspective. Instead, the woman was most often portrayed as an object of desire or scorn, described by a male character's voice or by a neutral narrator. For example, the classic tune "Pretty Polly," made famous by the Stanley Brothers in 1950, tells the tale of the title character's violent murder, caused by her lover's jealousy and shame. Further research revealed that there are many more of these murder ballads, often recounting the demise of young women who have rejected a man's affections. However, the masculine perspective is not reserved just for these ballads. The bluegrass genre, as has been discussed in previous research, has always been rooted in male expression. Furthermore, the "high and lonesome" style of singing that is associated with bluegrass is based on the timbral quality of the male falsetto and head voice. However, as bluegrass scholar Murphy Hicks Henry has proven, there have always been women playing and singing bluegrass music. But how do women, whose voice production functions differently, recreate this "high and lonesome" sound without the male falsetto? Fortunately, since the 1970s there have been a steadily increasing number of women who are playing and singing this music with much success, which allows me to venture for an answer to this question. My research on the bluegrass genre involves a comparison between genders and discussion of the role of women in the bluegrass industry, and I have approached the repertory and the literature on the topic with those interests in mind. As 
previously mentioned, women have been overlooked or marginalized in the telling of the bluegrass story, and this has only begun to change in very recent years. In this literature review I will point out how this gender bias has been written into bluegrass history.

\section{Literature Review}

While the musical genre of bluegrass music has now existed for approximately seventy years, it has received relatively little scholarly attention to date. First discussed in scholarly literature in 1965 , several scholars have since attempted to detail and capture the history and essence of a musical genre that seems to straddle the dividing line between folk and commercial music. Most scholars agree that Bill Monroe \& The Bluegrass Boys was the first band to play bluegrass music. Since then, the field has been marked by a wide range of approaches to understanding the music's performance practices, influences, and role in the broader context of American musical culture. While all of these contributions have helped to shaped the public perception of the genre, some are more comprehensive than others. Here I will offer a brief description of these texts and give a sense of how each one characterizes bluegrass music.

The earliest published work on bluegrass music is Mayne Smith's "Introduction to Bluegrass," published in the Journal of American Folklore in $1965 .{ }^{6}$ The essay emerged from his master's thesis on bluegrass music at Indiana University. While the essay is not a comprehensive history of the genre, Smith presents a well-rounded, concise portrait of the history of bluegrass

\footnotetext{
${ }^{6}$ Mayne L. Smith, “An Introduction to Bluegrass," Journal of American Folklore 78 (1965): 245-256.
} 
up to that point, looking at such topics as its cultural origins, instrumentation, repertoire, and its place in the music industry. Smith outlines the defining traits of bluegrass in five key points: ${ }^{7}$

1. "Bluegrass is hillbilly music: it is played by professional, white, Southern musicians, primarily for a Southern audience. It is stylistically based in Southern musical traditions.

2. In contrast to many other hillbilly styles, bluegrass is not dance music and is seldom used for this purpose.

3. Bluegrass bands are made up of from four to seven male musicians who play non-electrified stringed instruments and who also sing as many as four parts.

4. The integration of these instruments and voices in performance is more formalized and jazzlike than that encountered in earlier string band styles. Instruments function in three well defined roles, and each instrument changes roles according to the predictable patterns.

5. Bluegrass is the only full-fledged string band style in which the banjo has a major solo role, emphasizing melodic over rhythmic aspects...Every bluegrass band includes a banjo played in "Scruggs style" or some derivative thereof."

Moreover, Smith gives the most detailed musical analysis of the bluegrass style of all the published works on the genre. His groundbreaking article is cited by most of the subsequent works that are discussed here. In 1967, Smith also published a follow-up article titled "Additions and Corrections" to go along with the reprinting of the article in the popular magazine Bluegrass Unlimited. ${ }^{8}$ Another decade passed before anyone published a major work on the genre.

In 1975, two different histories of bluegrass were published. Both were written by bluegrass enthusiasts, and, although neither was written as a scholarly study, both serve as a general introduction to the genre. The first book, written by seasoned bluegrass mandolinist Bob

\footnotetext{
${ }^{7}$ Smith, "Introduction to Bluegrass," 245-246.

${ }^{8}$ Mayne Smith, "An Informal Autobiography," MayneSmith.com, 2008, http://www.maynesmith.com/bio-disco-bibliography.htm.
} 
Artis, was simply titled Bluegrass and gives a broad overview of the bluegrass style. ${ }^{9}$ Where the history is lacking in detail of analysis and origins, Artis makes up with love of the music and his own knowledge of the scene and industry as it stood at that point in time. The second book, inaccurately titled Old as the Hills: The Story of Bluegrass Music, was directed toward a general audience and provides a general overview of the style, also looking at the development of progressive bluegrass bands. ${ }^{10}$ Written in an informal style, this book can be best described as an enthusiast's impression of the musical style. The title is misleading, because bluegrass is relatively new compared to Appalachian folk tradition, and because it perpetuates the misconception that it is a type of folk music instead of the commercial genre that it is.

The mid-1980s witnessed the publication of the two most important and influential contributions to bluegrass scholarship. Bluegrass Breakdown: The Making of the Old Southern Sound, written by Robert Cantwell, was published first in 1984 and provides a multifaceted look at bluegrass music. In particular, Cantwell asserts that,

Bluegrass is the fruit of a union of Afro-American musical ideas with the European, especially the Celtic, on the folk and popular levels, and its roots are to be found in the popular culture of nineteenth- and early twentieth-century America, in blackface minstrelsy in particular, transformed by its sojourn in Appalachian folklife. ${ }^{11}$

This focus on the African American roots of bluegrass is a theme throughout many of the chapters. Instead of writing a chronological history, Cantwell switches lenses between chapters,

\footnotetext{
${ }^{9}$ Bob Artis, Bluegrass: From the Lonesome Wail of a Mountain Love Song to the Hammering Drive of the Scruggs-Style Banjo, the Story of an American Musical Tradition, (New York: Hawthorn Books, 1975).

${ }^{10}$ Steven D. Price, Old as the Hills: The Story of Bluegrass Music (New York: Viking Press, 1975).

11 Robert Cantwell, Bluegrass Breakdown: The Making of the Old Southern Sound (Chicago: University of Illinois Press, 2003), xix.
} 
exploring topics including correlations between bluegrass and jazz, the African origins of the banjo, the relationship between bluegrass and broadcast technology, and of course the history of the "Father of Bluegrass" himself, Bill Monroe.

The first several chapters of the book focus on this patriarchal subject, who receives a very favorable treatment from Cantwell, casting him as a culture bearer and at one point comparing him to the Buddha. ${ }^{12}$ After an anecdotal prologue detailing the behind-the-scenes happenings on the way to a Grand Ole Opry performance at the Capitol Center, Cantwell spends the next two chapters on Monroe, creating a mosaic-like portrait of the man using passages of biographical information alongside musings from Cantwell's interviews, meandering through different aspects of Monroe's personality and how he came to be the public persona we know today. This style continues throughout the book as he examines each topic, ultimately coming back to the Opry in the final chapter, driving home the assertion that Monroe has created a new form of American minstrelsy by putting a white face over a performance style rooted in African music traditions. $^{13}$

While comprehensive, Cantwell's story of bluegrass is written in such a way that it is difficult to follow any one narrative. Instead, the book is a patchwork of biographical information, musical analysis, and sociological study, sewn together with the author's own interpretations and experiences to capture the character and essence of the music Cantwell clearly loves and knows well. While he does not define bluegrass in a straightforward way, he does call upon Mayne Smith's definition as reference. ${ }^{14}$ It is also important to note that his version of this history is told through an almost exclusively masculine lens, with the women

\footnotetext{
${ }^{12}$ Cantwell, Bluegrass Breakdown, 9.

${ }^{13}$ Cantwell, Bluegrass Breakdown, 269.

${ }^{14}$ Smith, "Introduction to Bluegrass," 245.
} 
acting only as supporting characters in the story of the male musicians who created the genre, and some important women, like Bessie Lee Maudlin, Bill Monroe's long-time girlfriend and bassist for the Bluegrass Boys, receive no mention at all. In Chapter 9, titled "The High, Lonesome Sound: Ritual, Icon, and Image, Cantwell also spends several pages characterizing the bluegrass vocal style as a highly erotic expression of male sexuality, reinforcing the "boys' club" image of bluegrass music. ${ }^{15}$

The next major work on bluegrass, now considered to be the seminal text on the subject, came out just one year after Cantwell's landmark publication. In 1985, the University of Illinois Press published Neil Rosenberg's Bluegrass: A History. ${ }^{16}$ In this text, Rosenberg provides an impressively detailed chronology of the cultivation and evolution of the bluegrass genre, beginning in the days of hillbilly music, when Bill Monroe was still playing with his brothers. Rosenberg organizes the chapters by dates, allowing the reader to follow the timeline as it unfolds, and the narrative unfolds organically, through the relationships between the musicians who took bluegrass from a new kind of "mountain music" to a clearly defined genre of its own. Rosenberg spends two chapters on the Urban Folk Revival and the festival scene of the 1960s, paying special attention to how the intersection between the folk and bluegrass communities helped to open up and expand the audience for bluegrass, particularly on college campuses and in intellectual circles. ${ }^{17}$ Rosenberg also traces the gospel and old-time roots of bluegrass, acknowledging the importance of tradition and the deep ties to the geographical places where many of the songs came from. Additionally, he spends a chapter discussing the influence that bluegrass had on popular culture, particularly in film and television soundtracks, which was a

\footnotetext{
${ }^{15}$ Cantwell, Bluegrass Breakdown, 214.

${ }^{16}$ Rosenberg, Bluegrass.

${ }^{17}$ Rosenberg, Bluegrass, 174-175.
} 
reflection of this intersection happening at the folk festivals in the 1960s. Rosenberg then resumes his timeline, only to cut it off at 1974 . He then jumps to present day, 1984 at the time, to give a snapshot of how things have changed in ten years, including publications, the recording industry, the loyal fan base culture, and the music itself. Still, in his conclusion of the final chapter, Rosenberg insists that bluegrass is a traditional music at its core, an attribute which will ensure its survival as a genre in coming years, and that any deviation from that tradition would result in something different. ${ }^{18}$ This reinforces his own definition of bluegrass, which he delivers to the reader in the introduction under its own section titled "Bluegrass-What Is It?"19

Rosenberg study offers a thorough definition of bluegrass, addressing instrumentation and instrumental roles, vocal style, rhythm, form, repertoire, and performance practice. While Rosenberg's explanation lacks musical analysis, this is understandable, as he is more interested in examining the culture around the music. In the section following, Rosenberg also examines the debate surrounding the true starting point of bluegrass as a genre. Rosenberg refers to Mayne Smith's paper, which states that bluegrass became a genre when Lester Flatt and Earl Scruggs joined the Monroe's band in 1945, adding the three-finger banjo style that was widely replicated in the bluegrass bands that followed. ${ }^{20}$ Rosenberg asserts that it was the Stanley Brothers' imitation of The Blue Grass Boys playing style that defined the style as a genre. ${ }^{21}$

Here, like Cartwell, Rosenberg presents a very masculine portrait of the genre and development of bluegrass. Again, very few of the women listed in the index are given more than a brief mention. For example, when Sally Anne (Wilene) Forrester, who was a singer and

\footnotetext{
${ }^{18}$ Rosenberg, Bluegrass, 368.

${ }^{19}$ Rosenberg, Bluegrass, 6-10.

${ }^{20}$ Smith, "Introduction to Bluegrass," 246.

${ }^{21}$ Rosenberg, Bluegrass, 11.
} 
accordionist in an early Blue Grass Boys line-up, was first introduced into the bluegrass story, she was referred to only as Howdy Forrester's wife, who received two paragraphs of attention. ${ }^{22}$ Sally Forrester joined the band only a year after her husband in 1943 and played with them for three years, but Rosenberg makes no mention of it. ${ }^{23}$ Bessie Lee Maudlin also is snubbed by Rosenberg, her name not once mentioned in the text despite her twelve-year tenure with The Blue Grass Boys and her close long-term relationship with Bill Monroe. ${ }^{24}$

The absence of women from the bluegrass narrative prompted Murphy Hicks Henry, a professional banjo player, columnist, and pedagogue, to write her 2013 book Pretty Good for a Girl: Women in Bluegrass. Henry cites an incident at the 1993 International Bluegrass Music Association (IBMA) Awards as the motivation for researching women in the genre: My banjo-picking daughter, Casey, fifteen, and I sat in the audience and watched as a band of young male musicians, the Bluegrass Youth All-Stars, was referred to by one of the hosts as the "future of bluegrass music." I was livid. When told that the show's organizers had tried but couldn't find a young woman to be part of the group, I decided to start a database of women in bluegrass so that no one could ever use that excuse again. ${ }^{25}$

Starting in 1994, Henry published a quarterly newsletter, Women In Bluegrass, designing each issue to focus on a different female bluegrass musician, including profiles, interviews, and other short articles. ${ }^{26}$ Henry had also been writing a column for Banjo Newsletter, and the topics sometimes included her experiences as a female banjo player, as well those of other women in

\footnotetext{
${ }^{22}$ Rosenberg, Bluegrass, 55.

${ }^{23}$ Murphy Hicks Henry, Pretty Good for a Girl, 13.

${ }^{24}$ Henry, Pretty Good for a Girl, 46.

${ }^{25}$ Henry, Pretty Good for a Girl, 1.

${ }^{26}$ Casey Henry, "Women in Bluegrass," The Murphy Method, 2016, https://www.murphymethod.com/index.cfm?event=pages.content\&contentId=32.
} 
the bluegrass community. ${ }^{27}$ In the introduction to her book, Henry takes these previously mentioned authors to task, particularly Smith and Rosenberg, chastising them for their exclusionary definitions of bluegrass, and goes on to point out the instances were women were "blithely ignored." 28 "What about these women?" she asks. ${ }^{29}$ In this book, Henry sets out to answer that very question.

Organized chronologically and grouped by decade starting in the 1940s, each chapter focuses on an important female group or musician, some well-known, some never before mentioned. Henry's master's thesis, which she wrote on the "original Bluegrass Woman," Sally Ann Forrester, was later developed into the first chapter. ${ }^{30}$ While some of these women did have large-scale success in the industry, Henry also examines women whose impact was felt in local bluegrass music communities, the contributions of whom should not be undervalued. Certain chapters, particularly those in the earlier decades, focus on women in family bands, such as the Whites or the McLain Family, who likely would not have received due credit for their contributions, often mostly given to the male family or band members. At the beginning of each decade, Henry interjects herself, setting the scene in which these women appeared. At certain points in this narrative, Henry herself pops up, being a professional banjo player. However, she does so only briefly, providing her personal bluegrass history as the introduction to the section devoted to the 1970s, but mostly stepping back to let the other women's stories remain the focus. Of course, because the study focuses specifically on American women musicians in bluegrass, Henry had to omit many more women who have contributed to the bluegrass community and

\footnotetext{
${ }^{27}$ Henry, Pretty Good for a Girl, 1.

${ }^{28}$ Henry, Pretty Good for a Girl, 3.

${ }^{29}$ Henry, Pretty Good for a Girl, emphasis in original.

${ }^{30}$ Murphy Hicks Henry, Pretty Good for a Girl, 13-19.
} 
industry, such as international musicians, bluegrass disc jockeys, editors and publishers of bluegrass publications, and women musicians of closely related genres. ${ }^{31}$ In her conclusion Henry acknowledges that, while significant advancements in telling the story of women's role in crafting the genre of bluegrass have been made, there is still much work to be done.

Although Henry's study is the singular study devoted to women in bluegrass, other texts dealing with country music history, more generally, do include women in their narratives. Mary A. Bufwack and Robert K. Oermann's Finding Her Voice: Women in Country Music 1800-2000 functions as an encyclopedia of women in country music, spanning more than a century of music and studying a variety of country styles. ${ }^{32}$ Bufwack and Oermann's study also explores the parallels and intersections between country and rock and roll, including chapters on rockabilly and the country-rock of the 1970s. Furthermore, they include an entire chapter on the women of bluegrass. While each woman does not get as much individual attention as in the Henry text, the chapter is more inclusive of women who were a part of the community in roles besides musician, and the chapter covers the same timespan, giving a concise understanding of how women contributed to the bluegrass culture from its beginning to recent years.

In the past fifteen years, several scholars have attempted to address issues of gender in country music. Bill Hardwig, in his essay "Cocks, Balls, Bats, and Banjos: Masculinity and Competition in the Bluegrass Music of Bill Monroe," examines the strong masculine overtones of Bill Monroe's music, closely related to his love of horse racing, baseball, and cock fighting. ${ }^{33}$ While the focus of the article is not women, the acknowledgement of the strong masculine

\footnotetext{
${ }^{31}$ Henry, Pretty Good for a Girl, 6.

${ }^{32}$ Bufwack and Oermann, Finding Her Voice.

${ }^{33}$ Bill Hardwig, "Cocks, Balls, Bats, and Banjos: Masculinity and Competition in the Bluegrass Music of Bill Monroe," The Southern Quarterly 39, no. 4 (Summer 2001): 35-48.
} 
influence brings attention to the imbalance between both genders in bluegrass. In particular, Hardwig asserts that the popularity of murder ballads, such as "Pretty Polly" or "Banks of the Ohio" reflect the need to preserve the dominant masculine persona, which is threatened by potential infidelity or heartbreak. ${ }^{34}$

In 2004, a year after Bufwack and Oermann's work, Kristine McCusker and Diane Pecknold's essay collection Boy Named Sue: Gender and Country Music examined how country music and its culture interacts with and influences ideas of gender, both masculine and feminine. ${ }^{35}$ The chapters focus both on individual artists, such as Elvis and Patsy Cline, and also facets of the culture and industry, such as the WLS Chicago National Barn Dance and the gendered customs of a country dance hall.

In her 2008 dissertation titled "I Am a Honky-Tonk Girl:" Country Music, Gender, and Migration," Stephanie Vander Wel looks at how the "voices of female country artists provide representations of femininity and class. ${ }^{36}$ While looking at the ties between country music and place, Vander Wel also looks at how a wide variety of feminine identities are represented in the actual music sung by these "honky-tonk girls." As I will discuss in my own analysis, Vander Wel looks at different musical characteristics of songs performed by Kitty Wells and Loretta Lynn, including vocal timbre and range, and how they represent the lived experiences of men and women, revealing "the complexity of both real experiences and cultural representations of gendered lives." ${ }^{37}$ In a similar vein, Travis Stimeling's essay, "Taylor Swift's 'Pitch Problem'

\footnotetext{
${ }^{34}$ Hardwig, "Cocks, Balls, Bats, and Banjos," 45.

${ }^{35}$ Kristine M. McCusker and Diane Pecknold, A Boy Named Sue: Gender and Country Music (Jackson: University Press of Mississippi, 2004).

${ }^{36}$ Stephanie Vander Wel, "'I Am A Honky-Tonk Girl': Country Music, Gender, and Migration," doctoral dissertation, (University of California, Los Angeles, 2008), 27-28.

${ }^{37}$ Vander Wel, "Honky-Tonk Girl," 27.
} 
and the Place of Adolescent Girls in Country Music," reframes country singer Taylor Swift's pitch inaccuracies in performance as "an expression of a distinctly adolescent female approach to country authenticity" and discusses how the experiences of young girls and women, to which Swift's music speaks, are marginalized by country music listeners. ${ }^{38}$ Lydia Hamessley’s paper, "A Resisting Performance of an Appalachian Traditional Murder Ballad: Giving Voice to 'Pretty Polly," examines Appalachian murder ballads, which often depict the violent murder of a woman by her lover, and poses the question, "How might one perform these ballads with their misogynist and violent messages without seeming to condone or endorse them?" ${ }^{39}$ Hamessley looks for an answer to the question by focusing on the well-known murder ballad "Pretty Polly," studying an array of performers' interpretations, each of which handles the dilemma of the text differently.

One article, Stephen Sweet's “Bluegrass Music and its Misguided Representation of Appalachia," published in 1996, looks at how bluegrass music represents Appalachian culture, in part due to marketing practices, such as rural, old-timey imagery, which influence public perception of the genre's origins. ${ }^{40}$ While this article does not directly discuss women's contributions to the bluegrass genre or culture, it does acknowledge the significant amount of attention paid to the relationships between men and women in song lyrics. In his study, Sweet analyzed 211 songs recorded by 65 different bluegrass musicians in order to ascertain how well

\footnotetext{
${ }^{38}$ Travis D. Stimeling, "Taylor Swift's 'Pitch Problem' and the Place of Adolescent Girls in Country Music," in Country Boys and Redneck Women: New Essays in Gender and Country Music, Edited by Diane Pecknold and Kristine M. McCusker, (Jackson : University Press of Mississippi, 2016).

${ }^{39}$ Lydia Hamessley, “A Resisting Performance of an Appalachian Traditional Murder Ballad: Giving Voice to 'Pretty Polly," Women and Music: A Journal of Gender and Culture 9, no. 1 (2005): 15.

${ }^{40}$ Stephen Sweet, "Bluegrass Music and Its Misguided Representation of Appalachia," Popular Music \& Society 20 (1996): 38.
} 
they correlate with sociological observations of Appalachian life. ${ }^{41}$ Of the songs examined, 49 percent had dyadic relationships, involving two people, as their concern, and the topics of "love," "love lost," and "infidelity" were three of the most popular song topics. ${ }^{42}$ Sweet points out that the propensity for violence, particularly in the songs about lost love or infidelity, suggest a characterization of emotional immaturity in the Appalachian characters depicted, and also highlights the implication that the women are often the guilty party in these songs of infidelity.

Little research has yet been conducted on bluegrass vocal technique and style. Studies on closely related singing styles offer insight to how bluegrass vocalists use their instrument and from where they get their influences. The idea of a separate vocal pedagogy for commercial singing is a relatively new idea, so there is much research yet to be conducted. Brittny Kempfer's 2014 study, "Contemporary Commercial Music Pedagogy: Selective Exercises for Developing Healthy Technique in Adolescent Singers," voices this need. Her thesis examines the differences between male and female contemporary commercial singing and how each gender performs the style differently. Focusing with physiological data on the belt technique, which is frequently used in bluegrass music, Kempfer identifies the differences between male and female belting production, mainly in regard to the differences in the function of the muscles in the vocal folds. ${ }^{43}$ She identifies that, in both men and women, the distribution of control between the cricothyroid (CT) and the thyroarytenoid (TA) muscles is somewhat different. For both male and female singers, the TA muscles are dominant throughout the belt register, but the female belt is somewhat different in that there can be some cricothyroid control as the belt moves into the

\footnotetext{
${ }^{41}$ Sweet, "Bluegrass Music," 40.

42 Sweet, "Bluegrass Music," 45.

${ }^{43}$ Brittny Kempfer, "Contemporary Commercial Music Pedagogy: Selective Exercises for Developing Healthy Technique in Adolescent Singers," (Master's thesis, The University of Wisconsin, Milwaukee, 2014), 53-54.
} 
higher registers. ${ }^{45}$ Male singers, however, do not use their cricothyroid muscles until they switch into falsetto. Kempfer notes that it is much more difficult to define the female belt, because of the "differing vocal fold functions," referring to the mix between TA and CT control. ${ }^{46}$

The bluegrass vocal technique that is most closely related to this function is the yodel, on which music scholar Tim Wise has published studies, including his 2016 book Yodel and Meaning in American Music. Wise's book introduces the technical aspects of yodeling and how different yodels can be classified, providing a useful reference for the study of the style, using examples from popular music for reference. Wise defines a yodel as "singing in a manner that exploits noticeable breaks between natural/ modal and falsetto/ loft voice," the break made noticeable as a means of emotional expression. ${ }^{47} \mathrm{Wise}$ asserts that the exact moment of the break between the lower and higher registers, which he calls the yodeleme, is "the sonic event within the flow of the musical line that startles and delights the ear." ${ }^{48}$

Wise also separates English-language yodels into three main categories, depending on how the yodel relates to the text. A first species yodel functions like a melisma, where both the notes and registers are changing on one nonsense syllable. Second species, which is much more common, is a melismatic yodel sung within the context of a word, which was common practice in early country and blues singing. Third species, which is the type of yodel I will discuss in my own analyses, is what Wise calls a "yodeled grace note," used to ornament or emphasize a stressed syllable, but not an essential part of the melody. ${ }^{49}$ Wise also includes a chapter focusing

\footnotetext{
${ }^{45}$ Kempfer, "Contemporary Commercial Music Pedagogy," 48-49.

${ }^{46}$ Kempfer, "Contemporary Commercial Music Pedagogy," 52.

${ }^{47}$ Timothy E. Wise, Yodeling and Meaning in American Music (American Made Music Series) (Jackson: University Press of Mississippi, 2016), Kindle Edition, Ch. 1.

${ }^{48}$ Wise, Yodeling, Ch. 1.

${ }^{49}$ Wise, Yodeling, Ch. 1.
} 
on Jimmie Rodgers, who was thought to be the first country singing star. He had a profound influence on many musicians who followed him, including Bill Monroe. Wise also rightfully notes the considerable influence Rodgers took from the African American musicians he worked with, who often used the same kind of yodel technique in the blues. ${ }^{50}$ As with the origins of the banjo, we see the merger of African and European performance practices, combining to create an "American" sound.

In a similar study, titled "An Association between Breaking Voice and Grief-related Lyrics in Country Music," David Huron and Brandon Paul explore yodel techniques to see if there is a correlation between the stylistic device and themes of grief in country music. While their results showed that a song did not have to have an overall grief-related theme, the voice break can be considered a means of emotional expression, and is often used to highlight griefrelated words. ${ }^{51}$ (This correlation will be examined in my own study.)

Another paper, simply titled "Bluegrass Vocals," is an unpublished paper written by Fred Bartenstein in 2010, an accomplished musician who played with many of the First and Second Generation bluegrass musicians, spending a lot of time on the bluegrass festival circuit. He is also responsible for the definition of those generations, which he presented at the first Bluegrass Music Symposium in $2005 .^{52}$ In addition to playing bluegrass, Bartenstein also worked as a bluegrass deejay for most of his life, starting in his teens, and founded a bluegrass publication,

\footnotetext{
${ }^{50}$ Wise, Yodeling, Ch. 1.

${ }^{51}$ David Huron and Brandon Paul, "An Association between Breaking Voice and Grief-related Lyrics in Country Music," Empirical Musicology Review 5 (2010): 27, EBSCOhost (201006380).

${ }^{52}$ Fred Bartenstein, "Bluegrass Generations," Bartenstein and Bluegrass, 2014, http://www.fredbartenstein.com/bluegen.html.
} 
Muleskinner News. ${ }^{53}$ Based on his extensive experience both playing and listening to bluegrass music, "Bluegrass Vocals" offers a basic breakdown of different styles of bluegrass singing. However, there are some shortcomings in this model, which I will examine later. Bartenstein does not explore the physiological side of the production of these techniques, but instead he studies the cultural influence of each style. Using a modified Punnett Square, which is typically used to predict biological genotypes, Bartenstein looks at two types of production, belting and crooning, and two types of inflection, rural and urban, which creates four bluegrass singing styles- rural belter, urban belter, rural crooner, and urban crooner $^{54}$. Where the production style can be more of a stylistic choice, the inflection reflects the singers own background, with "rural" referring to performers who come from a more isolated, perhaps Southern community, whereas "urban" refers to singers who come from more populated areas or are from the North. ${ }^{56}$ The belting style originated in a time before the invention of microphones. In order to be heard over a band in a noisy setting, the singer had to project and sing in such a way that it would cut through the noise, resulting in a bright, powerful straight-tone vocal. The crooning style emerged after the widespread use of microphones, which allowed singers to perform with more subtlety and nuance, including vibrato and lower volumes. Bartenstein also includes information on duets, trios and quartets, giving his own advice along with the historical background for the different techniques. Bartentstein then gives his predictions for where bluegrass singing might be going in the future.

${ }^{53}$ Fred Bartenstein, "Bluegrass Vocals," (working paper, Bartenstein and Bluegrass, Yellow Springs, 2010), http://www.fredbartenstein.com/bgvocals.html.

${ }^{54}$ Bartenstein, "Bluegrass Vocals."

${ }^{56}$ Bartenstein, "Bluegrass Vocals." 
My own research draws upon the models offered by these earlier studies. On one level, I look closely at how each performer uses their own voice in the context of bluegrass, and I draw on the Bartenstein paper, as well as Wise's research on yodeling. My research also resembles Paul and Huron's study, because I am looking at how the performer's use such stylistic devices to express the emotional content of the text. The other layer to my research focuses on gender and my analysis of the audio-recorded vocal performance, specifically the stylistic choices that the performers make in relation to the lyrics. My hope here is to better understand how the artists engage with and convey the emotional content of the lyrics with their voices. Furthermore, through comparison I examined how the two groups, early make and contemporary female performers, approach this content differently. This element closely compares to Hamessley's research, since I also am looking at "Pretty Polly." While I am also interested in finding more progressive interpretations of these songs, my study is different, because I am drawing a direct comparison between genders and generations of bluegrass performers, where Hamessley's study was less focused on the gender of the performers and more on the "resisting" nature of their performances. $^{57}$

\section{Methodology}

To limit the scope of the study, I have condensed my research interests into three main questions, which will be addressed in chapters two, three, and four of this paper. First, how do the original male bluegrass performers use their voices to engage with the text, and how do their performances compare and contrast? Because the early bluegrass singers were all closely mimicking Bill Monroe's style of singing, I predicted that there would be many similarities with

\footnotetext{
${ }^{57}$ Hamessley, "Giving Voice to 'Pretty Polly,"' 21.
} 
only a few select stylistic differences. For the second chapter, I ask the same questions regarding the contemporary female performers. Because they come from different musical backgrounds, I predicted that I would find a greater variance between their stylistic choices. Third, I compared the male and female performers to each other.

In this third chapter, there are several things that need to be taken into consideration. First, we are looking at two different generations of bluegrass musicians with different broader musical contexts. When the earliest of these male recordings, Monroe's "In the Pines," was made in 1941, the technology for commercial music recordings had only been available for approximately twenty years following the end of World War I, meaning the production quality is not going to be on the same level as the new recordings. ${ }^{58}$ One also has to consider all of the musical developments and movements that have occurred in the time between the recordings. Many popular music styles have changed and evolved since Monroe, Stanley, and Osborne came on the scene, and the contemporary female performers may draw influence from beyond the bluegrass genre. It is also important to note that, for the sake of scope, I am not discussing recordings made by early female singers or contemporary male singers. Additional study focusing on these groups of performers may give further insight into how the style is performed across generations and between genders.

My first step in the process was to transcribe all of the recordings. I selected four wellknown bluegrass songs which each have been recorded by at least one early male singer and one female bluegrass singer in the last fifteen years. Each song presents different poetic themes in the text which are often associated with the bluegrass genre. The first song, "In the Pines" was

58 Ted Olson and Charles K. Wolfe, The Bristol Sessions: Writing About the Big Bang of Country Music (Jefferson: McFarland, 2005), 1. 
recorded by Bill Monroe \& the Bluegrass Boys in 1941 and by Della Mae, featuring vocalist Celia Woodsmith, in 2010. This song is a heartbroken lament which also glimpses the life of a railroad worker in the early to mid-Twentieth Century. The second song, "I'm Working on a Building," was also recorded by Bill Monroe \& The Bluegrass Boys in 1954 and by Patty Loveless in 2009. This is a straightforward gospel song that talks about building a church to honor the Lord. The third song, "Pretty Polly," is the only traditional ballad of the set, and was recorded by The Stanley Brothers in 1950, featuring Ralph Stanley on vocals, and by Abigail Washburn in 2014. This song is a murder ballad which explicitly discusses a man, Willie, murdering his lover, Polly, in part because of her sullied reputation. The fourth song, "Bluegrass Express," was originally recorded by The Osborn Brothers in 1964, featuring Bobby Monroe on vocals and by Rhonda Vincent in 2001. Bluegrass songs often talked about trains, which were a symbol of homesickness, loneliness, and travel, and "Bluegrass Express" uses that symbol again to express the excitement of returning home.

I limited my transcriptions to the vocal line of the lead singer, with the exception of Bill Monroe's tenor part his recording of "In the Pines." Monroe's high tenor voice was what inspired the vocal style, so I felt it was appropriate to use his vocal line instead of the lead. In addition to the melodic and rhythmic elements of the transcriptions, I also paid close attention to stylistic traits, such as scooping, slides, pitch bending, and vocal breaks, as were described in Tim Wise's research. For the scooping and slides, I put the marking next to each note. To indicate the voice break, I put an uppercase " $\mathrm{B}$ " where the break occurs in the melody. An example of the markings can be seen below. 


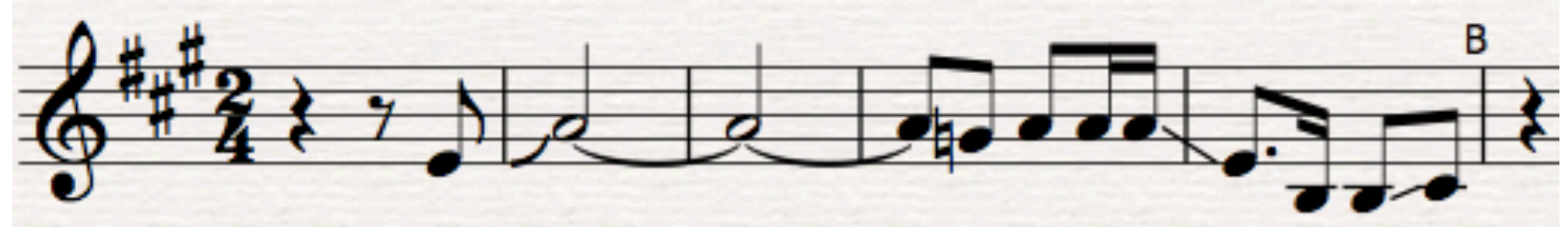

Figure 1. Excerpt from Patty Loveless' recording of "Working on a Building" which shows the marking for vocal scoop (m. 2), slides (mm 4-5), and vocal breaking (m. 5).

When analyzing the transcriptions, I focused on range of the melody, vocal registers, and stylistic traits chosen by the performer. In order to identify the switch between registers, I listened for timbral changes in their vocal production, and I used the vocal pedagogy text Vocal Technique: A Guide for Conductors, Teachers, and Singers by Julia Davids and Stephen LaTour as a reference for where the transitions typically fall for male and female voice types. My main concern with vocal registers had more to do with how women might recreate the sound of male falsetto, which typically has a more noticeable register transition. ${ }^{59}$ I make frequent reference to their definition of mixed register, which is a blending of upper and lower register production. ${ }^{60}$ This has to do with the distribution of control between the cricothyroid (CT) and the thyroarytenoid (TA) muscles over the vocal folds. There are two classifications of mixed voice; Mx1 has dominant thyroarytenoid control and is produced more in the lower register, and Mx2 has dominant cricothyroid control and is produced more in the upper register. ${ }^{61}$ I also relied on Tim Wise's research as a reference for the use of yodels, which originated in early country singing styles, in these songs. ${ }^{62}$

${ }^{59}$ Julia Davids and Stephen LaTour, Vocal Technique: A Guide for Conductors, Teachers, and Singers (Long Grove: Waveland Press, 2012), 154.

${ }^{60}$ Davids and Latour, Vocal Technique, 148.

${ }^{61}$ Davids and Latour, Vocal Technique, 149.

${ }^{62}$ Wise, Yodeling, Ch. 5. 
My second area of focus has to do with commonalities throughout the data set. Among the recordings made by the female performers, are there common stylistic traits that can be found? How do they relate to the common traits in the recordings made by the male performers? In the process of selecting musicians for the study, I deliberately chose female performers who not only have distinctly different voices, but who also have a range of different musical backgrounds. I predicted that, despite these differences, common stylistic choices would be found between some, if not all singers. I also aimed to demonstrate that there should be a much broader definition of what bluegrass singing sounds like. After the comparison between the women, I compared the traits to the older male performances to see if any of these common choices could be found. I predicted that while there would certainly be some early techniques in this group, it is possible that other techniques have been picked up from other sources over time that might be heard in the contemporary performances. 


\section{Chapter 2: Analysis of Early Male Performances}

The bluegrass style was not actually defined as a genre until the mid-50s, but musicians had been playing in the style for at least a decade by that time. ${ }^{63}$ Originating with Bill Monroe and his band, The Blue Grass Boys, the style quickly became popular after Earl Scruggs joined the band in 1945, bringing his three-finger style banjo playing, which would be replicated by many other bands soon after. ${ }^{64}$ However, that was not the only part of the new country music style that would become a defining element of the genre. With his high-soaring falsetto and bright, cutting tone, Bill Monroe's singing style, along with his harmony arrangements, would also be frequently mimicked. As a result, many of the recorded bluegrass performances from the $40 \mathrm{~s}, 50 \mathrm{~s}$, and $60 \mathrm{~s}$ feature this unique singing style, including the four recordings analyzed in this chapter. Two of the recordings were made by the originator, Bill Monroe, and the other two are made by musicians who were in close contact with Monroe. The Stanley Brothers were one of the first bands to directly copy Monroe's style with considerable success, and The Osborne Brothers both started playing bluegrass in 50's, Sonny Osborne playing as a Blue Grass Boy in the early 50 s. ${ }^{65}$ While each performer had his own unique voice, they all draw upon many of the same core techniques.

\section{"In the Pines"}

Bill Monroe grew up with a wide variety of musical influences, which all came together to become his unique bluegrass singing style. He grew up in a very musical family, and when they were not working on the farm, they were often making music together as a family band.

\footnotetext{
${ }^{63}$ Neil V. Rosenberg, Bluegrass: A History (Chicago: University of Illinois Press, 2005), 11. ${ }^{64}$ Rosenberg, Bluegrass, 11.

${ }^{65}$ Neil V. Rosenberg and Charles K. Wolfe, The Music of Bill Monroe (Urbana: University of Illinois Press, 2007), 91.
} 
While he and his five siblings were all fine instrumentalists, they also received instruction and influence on singing, first from their mother, who was a ballad singer, as well as at church, where teachers would often hold singing schools and teach shape-note singing. Bill also had a keen interest in the music of the black communities of his hometown Rosine. He paid careful attention to how they played and sang the blues, and to the gospel quartets that were so popular in the $1920 \mathrm{~s} .{ }^{66}$ There is one musician in particular, Arnold Schultz, who performed often in Rosine when Monroe was a teen, and Monroe cited him as a strong influence, incorporating Schultz's blues style into his performances. ${ }^{67}$ He also listened to the earlier hillbilly country musicians, particularly Jimmie Rodgers, who incorporated the blues yodel into his music. ${ }^{68}$ With his high tenor voice and strong falsetto, Monroe was able to imitate these yodels, an element that would carry over into the bluegrass vocal style.

Referred to as the "high and lonesome sound," 69 this bluegrass style relied on a singer being able to access those high notes with some ease. The average amateur tenor range typically falls between $\mathrm{C} 3-\mathrm{A} 4$, with the professional range extending up to $\mathrm{C} 5 .^{70}$ In his early hits from the 1940s and 1950s, Bill Monroe sang in the professional range despite having little formal training $^{71}$. The vocal lines often demonstrated a high tessitura, sitting in the top half of the range, most often centering around G4. For example, in the remade version of "Blue Moon of

\footnotetext{
${ }^{66}$ Rosenberg, Bluegrass, 28-30.

${ }^{67}$ Erika Brady, "Contested Origins: Arnold Schultz and the Music of Western Kentucky," in Hidden in the Mix: The African American Presence in Country Music, edited by Diane Pecknold (Durham: Duke University Press, 2013), 102-103.

${ }^{68}$ Rosenberg, Bluegrass, 22.

${ }^{69}$ Rosenberg, Bluegrass, 7.

${ }^{70}$ Julia Davids and Stephen LaTour, Vocal Technique: A Guide for Conductors, Teachers, and Singers (Long Grove: Waveland Press, 2012), 160.

${ }^{71}$ Richard D. Smith, Can't You Hear Me Callin': The Life of Bill Monroe, Father of Bluegrass (Boston: Little, Brown and Co, 2000), 21.
} 
Kentucky," which he recorded in 1954 for Decca, ${ }^{72}$ Monroe's vocal range is F3-C5. He sings higher still on the song "New Mule Skinner Blues," the melody soaring to an Eb5. This recording in particular, a tribute to Jimmie Rodgers, shows clear imitation of Rodgers' yodel technique, which Monroe modified slightly putting "a laugh on the end of it." ${ }^{, 73}$ While Monroe did perform some songs that sit in the lower part of his range, such as the early recording of "Footprints in the Snow," they are less commonly found in Monroe's discography.

Both of Monroe's recordings included in this study have a high tessitura. Recorded in 1941as a B side, "In the Pines" features Bill Monroe singing tenor with Bill Wesbrooks on the lead vocal. ${ }^{74}$ Although Monroe was the band leader, he often sang the secondary parts, because he was known for his "high and lonesome" tenor and was hesitant to feature his singing on recordings. ${ }^{75}$ In this song, Monroe uses a wider range than most of his other recorded songs, his performance spanning a range of two and a half octaves from Ab3 to E5. The verses and choruses are sung in the $\mathrm{Ab} 3$ to $\mathrm{E} 4$ range consistently throughout the recording. The only time Monroe uses the higher octave is during the interlude between the choruses and the next verse. There is no text here, and Monroe and Martin sing on a "woo" syllable to imitate the "cold wind" that is described in the lyrics. In order to be able to sing with such a wide range, Monroe had to use multiple vocal registers, which he incorporated into the singing style.

It is clear from Bill Monroe's recorded performances that he was very aware of the timbral differences of his vocal registers and how they could be used effectively as a stylistic tool. In "In the Pines," Monroe switches between a mixed head voice and high falsetto to create a

\footnotetext{
${ }^{72}$ Rosenberg and Wolfe, Bill Monroe, 110.

${ }^{73}$ Jocelyn R. Neal, The Songs of Jimmie Rodgers: A Legacy in Country Music (Bloomington: Indiana University Press, 2009), 57.

${ }^{74}$ Rosenberg and Wolfe, Bill Monroe, 31.

${ }^{75}$ Rosenberg and Wolfe, Bill Monroe, 31.
} 
dramatic contrast. In the verse and chorus sections, Monroe sings in the middle of the established tenor range, moving around the first passagio, which Davis and Latour identify as around C4. Even at the melodic climax of these sections, Monroe sings no higher than an E4, which is somewhat uncharacteristic of his singing. However, after each chorus there is a brief interlude, sung on a "woo" syllable, which abruptly jumps up an octave from G\#3 to G\#4, with the interlude ranging from G\#4-E5, some of the highest recorded singing performed by Monroe, which can be seen in the score excerpt below.

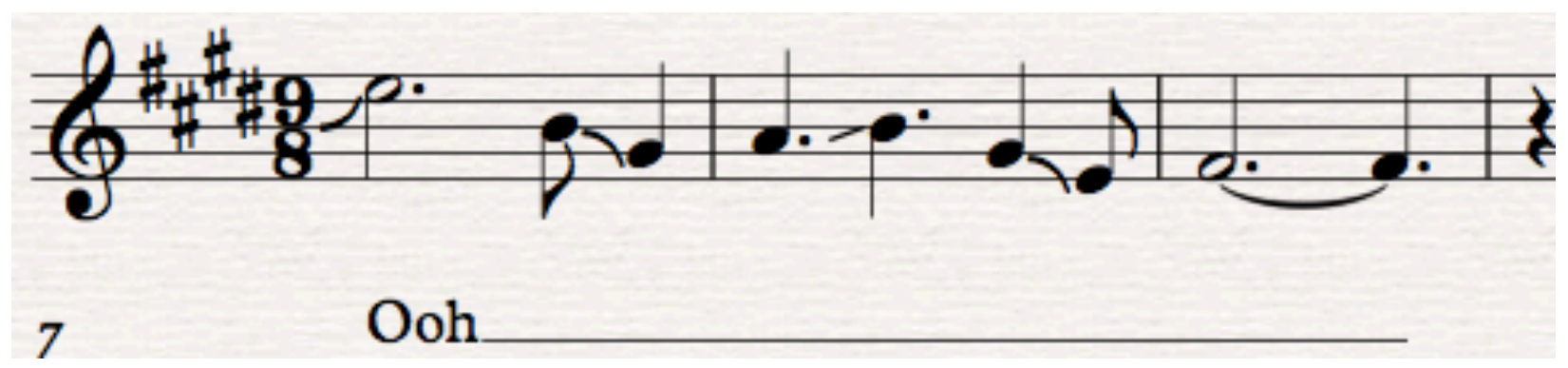

Figure 2. Excerpt from Bill Monroe's recording of "In the Pines," showing the top of Monroe's range on the recording, E5.

The falsetto singing in these passages has a thinner, "hooty" sound to it, which is a result of the vocal cords only vibrating at the outer edges. ${ }^{76}$ Monroe was known for this unique vocal and was heavily inspired by the yodeling style of earlier singers like Jimmie Rodgers. ${ }^{77}$ It can be a difficulty to sing loudly in falsetto, which is why Monroe's singing disappears slightly, such as in measures $31-32$, but then returns as the voices move higher. Perhaps if he had been able to use our modern recording technology, the subtlety could be heard. It is also interesting to note the timbral difference between the E4 sung in the verse and chorus, such as in mm. 25, and the E4 sung in the interlude, seen in mm. 33. Here, Monroe is not noticeably switching back into the fuller head voice that he had been using in the previous sections. That he is able to navigate the

\footnotetext{
${ }^{76}$ Davids and LaTour, Vocal Technique, 151.

${ }^{77}$ Neal, Jimmie Rodgers, 57.
} 
second passagio between head voice and falsetto with ease shows the extent of Monroe's mastery of his instrument.

Because the falsetto register packs considerably less force, even when well developed, Bill uses his onsets and cutoffs to reinforce the dramatic strength of his phrases. For example, in the song "In the Pines," Monroe uses an aspirated onset during the falsetto interlude, seen in the first measures of the transcription, singing on an aspirated /hu/ instead of a pure / $\mathrm{u} /$ vowel. Where in classical singing this would be seen as a vocal fault to be corrected, here it is a favorable addition. ${ }^{78}$ In conjunction with the aspirated onsets, Monroe also uses abrupt drop-offs and slides to lower pitches, giving a forcefully abrupt, rhythmic feel to the line, closer to the power of a head voice belt. These rhythmic accents also suggest a whistling of the harsh wind that Monroe sings about in the song. To erase any doubt of this interpretation, there is a musician making a soft blowing whistle noise as the interlude is being sung.

Monroe also makes ample use of slides in all sections of "In the Pines," but more in the verses than anywhere else. The general mood of the song is gloomy, with lyrics discussing a lost lover, as well as work on the railroad, a theme that is often associated with loneliness in bluegrass music. A moment when the slide technique is especially effective can be seen at m. 26 . Monroe uses a long slide on the word "cold" to draw out its emphasis, and then a drop off into the word "wind." The same effect is used in mm. 98-99 for the lyrics "leave my home." In addition to the slides, scoops and drop-offs are used to create the gloomy effect, and the sound resembles that of someone weeping. There is one instance where Monroe uses a grace note that is not heard in other verses. At the dramatic climax of the song in m. 96 , sings a quick $\mathrm{C} 4$ before landing on the B3 to accent the dramatic verb "mourn."

${ }^{78}$ Davids and LaTour, Vocal Technique 185. 
Another important stylistic device that Monroe uses in this song is a vocal break. This can be described as "a rapid alternation between falsetto and modal [chest and head] vocalizations." 79 In his study on yodeling, Timothy Wise identified this technique as a mode of "some kind of expression of emotion or significance." ${ }^{80}$ This technique can often be heard in lamenting country and bluegrass songs, like this one, but is not limited to this subject matter. ${ }^{81}$ Monroe uses the technique the most in the verses. In the first verse, it can be heard twice in $\mathrm{m}$. 57 at the climax of the phrase where he is singing the lyric "I'm on my way back home," adding emphasis to the declaration. Monroe uses the voice break twice as much in the second verse, the lyrics of which address the "girl" who abandoned the man in the song, and it gives the verse a weepy quality. He again uses two breaks in rapid succession at the climax of the phrase in m. 97, and then also adds one more on the word "home" at the end of the verse.

\section{"Working on a Building"}

The second song in the study performed by Bill Monroe, "Working on a Building," shares a number of similarities with "In the Pines." As was common, Monroe performed the tenor part in the chorus with Jimmy Martin singing the lead. ${ }^{82}$ However, Monroe sang lead on the verses instead of Ewing and stayed up the octave in the high tenor range. Recorded in 1954 in the key of A major, ${ }^{83}$ Monroe's recording sounds notably different from the earlier recording

\footnotetext{
${ }^{79}$ David Huron and Brandon Paul, "An Association between Breaking Voice and Grief-related Lyrics in Country Music," Empirical Musicology Review 5, (2010): 27. EBSCOhost (201006380).

${ }^{80}$ Timothy E. Wise, Yodeling and Meaning in American Music (American Made Music Series) (Jackson: University Press of Mississippi, 2016), Kindle Edition, Ch. 1.

${ }^{81}$ Huron and Paul, "Breaking Voice," 31.

${ }^{82}$ Rosenberg and Wolfe, Bill Monroe, 109.

${ }^{83}$ Rosenberg and Wolfe, Bill Monroe, 109.
} 
made by the Carter Family in 1934, in which Maybelle Carter sang lead down the octave in F major throughout the entire song. This reveals a very clear artistic choice; he very well could have sung the song down the octave in the same range as Carter, where he had performed other songs, but he chose to perform it in the high tenor range that he was known for.

Because his full vocal range would have allowed a lower performance, the high tenor is very clearly a stylistic choice that he made, and one that would define his career and the bluegrass genre. With a couple brief exceptions, most of his performance on this recording falls into the octave range of A3-A4. The verses sit predominantly on and around A5, but the chorus tenor line moves in a wave like pattern through the octave, spanning the full range of Monroe's performance. It is also during this section that he accents the tenor line by jumping up to the C5, though he waits until the second chorus to start using the accent. Here again Monroe uses his range, as well as the contrast between his different vocal registers, as a stylistic to accent the climax of the chorus and build the song musically.

In "Working On a Building," the shifts between registers in Monroe's voice are much easier to discern, though he seemingly does so with great ease. If a falsetto register has been properly developed, it can sound more like head voice and the break between the two registers is not as obvious. However, a noticeable shift was typical of the style, in part because many people singing this style of music in the early years were not formally trained singers. Instead, this was incorporated into the bluegrass singing style. Much of his singing in both the verses and choruses sits on A4, which sits just above the second passagio. While Monroe is able to blend the passagio well, the shift between falsetto and head voice is most obvious at moments such as that found in mm. 22-23, where he quickly descends from A4 to A3. The fullness of his vocal timbre and its 
volume increase as he enters his chest voice. The break between his head voice and falsetto, is very subtle, but can be heard best in instances like at mm. 19 or mm. 28-29.

"Working On a Building" is a gospel song and has a much different poetic tone that "In the Pines. His performance is much more straightforward here, but again he can be heard using the sliding technique. He uses it most noticeably on the words "building" and "Lord," such as in measures 28 and 32, respectively. These are poetically the two most important important words in the song, because they both connect to the religious theme of the text, and the slide technique serves to highlight them for the listener. The slide is also used in combination with a descending leap of a fifth to highlight the different themes of each verse. It can be heard on the words "gambling" in m. 23, "drinking" in m. 63, and "preaching" in m. 104 for the first, second, and third verses respectively. Monroe also uses this technique on the word "do" in the first verse at m. 21, but he changes his approach later in the song. In the second and third verses he uses a pitch bend on the same word, a technique similar to the slide, where he attacks the A4 pitch with a hard /d/ consonant, immediately dips down a half step to Ab5, and then gradually slides back up to the starting pitch. In the third verse, his attack on the consonant is even more aggressive than the last, as a means of building excitement. This technique is also used again at the very end of the song as a sort of cadenza on the repetition of the words "for my Lord," slowing down and stretching each word, while sliding and pitch bending each one. 


\section{"Pretty Polly"}

The Stanley Brothers were one of the first bands to directly imitate Bill Monroe and The Bluegrass Boys and replicated the style with considerable success. Monroe's singing style was an integral part of that style, so Ralph Stanley, lead singer of the Stanley Brothers, closely imitated Monroe's singing. Like a young Monroe, it was not common for Ralph to sing lead vocals, instead opting to sing the tenor lines to his brother, Carter's, lead. However, on the Lonesome River Valley session in 1950, he recorded two old mountain ballads as a soloist. One was the murder ballad, "Pretty Polly." 84 It is significant to note that Stanley learned this tune from his father, a logger and also a singer, who had a love for the old ballads. While we do not have a recording of Stanley's father singing, it can be supposed that he passed on the earlier style of ballad performance to his son Stanley, which in turn had an influence on this specific performance.

In this example, Stanley sings as a tenor, but with a much lower range than that used by Monroe, spanning and octave and a third, F3-A4. Like most older ballads, "Pretty Polly" is strophic, and in each verse, one line of text that is repeated. On the repetition of the line, Stanley leaps up a tritone from B3 to F4, which, by contrast, gives emphasis to the reiteration of the text. The rising in pitch also emphasizes the tension and drama of the storyline. At the end of each verse, however, the melody completes the arc by returning to the tonic at the bottom of the range. While Ralph Stanley does not have the exceptionally high range that Monroe showcases, he still uses his upper tenor range with considerable affect.

${ }^{84}$ Gary B. Reid, The Music of the Stanley Brothers (Urbana: University of Illinois Press, 2015), 37. 
In contrast with Monroe's performance, Ralph Stanley's singing in “Pretty Polly” sits much lower and does not use any falsetto whatsoever. Stanley was known for singing the high tenor parts on Stanley Brothers recordings, so it was not so much that he could not, but that the song warranted a lower-voiced performance. ${ }^{85}$ Traditional ballads like "Pretty Polly" were written with the aim of telling a story, and the simple and repetitive melody and rhythm helped the lyrics to be heard more clearly and not detract from the narrative. ${ }^{86}$ In this song, Stanley switches between chest and head voice to create contrast. In the first line of the verse's melodic structure, he sings between F3 and B3, which is in chest voice, just below the first tenor passagio. On the repetition of the text in the second line, Stanley sings up the octave and is singing in head voice. However, there is generally not a distinct timbral difference between chest and head voice in performance, especially around the first passagio.

While Stanley does not switch into his falsetto register for this song, the second passagio is noticeable when he leaps up to the A4 in the second line of the melody. Like Monroe, Stanley is a "rural belter," a style of straight-toned singing that uses very little vibrato and tends to have a pushed quality, especially for male performers singing around that second passaggio. ${ }^{87}$ However, this pushed tone quality was actually a part of that "high and lonesome" sound that was so desirable for early bluegrass singers. In part, the "high lonesome" sound derives from the tradition of early Appalachian singing where the performer would have to be able to project without a microphone. ${ }^{88}$ This is also why belters typically use very little to no vibrato.

\footnotetext{
${ }^{85}$ Reid, Stanley Brothers, 119.

${ }^{86}$ Encyclopedia of Appalachia, s.v. "Ballads," accessed October 22, 2016, http://www.encyclopediaofappalachia.com/entry.php?rec=31.

${ }_{87}$ Davids and LaTour, Vocal Technique, 151.

${ }^{88}$ Fred Bartenstein, "Bluegrass Vocals," (working paper, Bartenstein and Bluegrass, Yellow Springs, 2010), http://www.fredbartenstein.com/bgvocals.html.
} 
While Stanley is a rural belter, demonstrating that type of singing in his performance on "Pretty Polly," his approach is a little different than those of Monroe. Having grown up in the hills of Virginia, Stanley learned how to sing the old Appalachian ballads at home. Ralph's brother, Carter, attributes their ballad learning to their father, who knew a few and sang them without accompaniment, "Pretty Polly" being one of them. ${ }^{89}$ These ballads are traditionally sung a capella or with fiddle accompaniment and with emotional detachment, regardless of the subject matter. ${ }^{90}$ While Stanley is singing with a full bluegrass band, he replicates the traditional style of singing that he grew up hearing in the hills. Like the other two singers, Stanley sings with a straight-tone belt, which gives a forceful, strident effect. Because of the sparse, straightforward nature of ballad performance, voice breaks and scooping would have sounded too emotional and out of place. However, he was still able to add some musical variety by playing with the rhythmic structure of the verses and the sounds of the words themselves.

Stanley uses dotted rhythms throughout the song, and the quick sixteenth notes give the melodic line an angular, tense character. While it was not stylistically appropriate to show emotion when reciting the ballad, this approach suits the character Willie's cold-hearted treatment of Polly. There are instances where Stanley uses a more even rhythmic pattern, which stands in contrast. There are several spots where he uses quarter note triplets, most often used in phrases that pose a question. This is first seen in the second verse at mm. 144 and 151, accompanying the lyrics "he led her a little farther and what did she spy?" He uses a triplet both times the phrase is sung, the first time on a held B3, but the second time outlining a B major triad, giving extra emphasis to the words "what did she." In this same verse, Stanley also sings

\footnotetext{
${ }^{89}$ Reid, Stanley Brothers, 29.

90 Encyclopedia of Appalachia, s.v. "Ballads."
} 
the phrase "new dug grave" with straight quarter notes, which allows the words to stand out of the texture. The second time the triplets are used is in the last verse in mm. 223 and 228, posing the similar question, "what did he say?" Two measures of quarter note triplets are also used in two instances where the lyrics talk about travel. The first is in the second verse in mm. 67-68 on the phrase "led her over mountains and valleys so deep," with the triplets accentuate the imagery of the words "mountains and valleys." The second example comes in the third verse on the words "rambling you lead me astray," using the same melodic structure as the first example.

One more device Stanley uses that is also commonly found in traditional ballad singing is to add extra beats to a phrase, making the tune "crooked." There are two instances where Stanley does this, both in the second half of the song. In mm. 163 Stanley includes an extra beat on the word "knelt" in the repetition of the phrase "she knelt before him," which adds to the drama of the scene. The second time he uses this device is in the last verse on the word "went," a verb associated with movement, of the phrase "he went to the jailhouse, which poetically makes sense.

\section{"Bluegrass Express"}

The Osborne Brothers signed their first recording contract in 1956 after having gained experience on the WJR Detroit and WWVA Wheeling barn dance shows. ${ }^{91}$ The two brothers had already played in various bands, Sonny Osborne playing for a while with Bill Monroe, his brother, Bobby, playing with the Stanley Brothers. ${ }^{92}$ Because of their time in these bands, they were well-versed in the original bluegrass style and were ready to carry on the tradition, but not without some innovation. Out of necessity, the Osborne Brothers experimented with the standard

\footnotetext{
${ }^{91}$ Bill C. Malone and Jocelyn R. Neal, Country Music, U.S.A. (Austin: University of Texas Press, 2013), 339.

92 Rosenberg and Wolfe, Bill Monroe, 91.
} 
vocal arrangement found in most bands at the time, opening up new possibilities. Bobby Osborne was a tenor, but felt limited by being forced to sing the tenor parts, so the Osborne brothers developed a style called the "high lead" trio in which the lead melody was sung in the highest voice and the tenor harmony sung underneath. ${ }^{93}$ This is not unlike Monroe's own performance in “Working On a Building," in which he sings both the tenor parts and the lead. Sonny had been playing with The Blue Grass Boys around the time of that recording and may have taken some influence from Monroe.

The Osborne Brothers' song "Bluegrass Express" is a perfect example of this "high lead" vocal arrangement that they had come to be known for. Recorded in 1964, it features Bobby Osborne on the high lead, which we will be focusing on in this study, Sonny Osborne on the tenor line, and Benny Birchfield on Baritone. Singing in the key of D, Osborne's performance spans an octave, from A3-A4, which, according to the Davids and Latour text, is the top half of the standard tenor range. ${ }^{94}$ In the choruses, Osborne sits much higher in this range, centering around F4 and reaching the climax of the melody towards the end of the section on the A4. The verses are pitched much lower, sitting on the B3 for the whole first phrase. The melody line gradually ascends in a loose circle of fifths progression until the verse finishes on the starting pitch of the chorus, F4.

Bobby Osborne also falls in the rural belter category. In his performance on "Bluegrass Express," he sings with a higher tessitura than Ralph Stanley does on "Pretty Polly" and consequently uses more of that pushed vocal production. Starting on the chorus, Osborne is singing comfortably in his head voice at an F4. At the peak of the chorus he leaps up to A4 and

\footnotetext{
${ }^{93}$ Rosenberg, Bluegrass, 155.

${ }^{94}$ Davids and LaTour, Vocal Technique, 160.
} 
this is where we can hear him approaching the passaggio, the tone being brighter and thinner. His voice also does occasionally and very briefly flip into the falsetto, creating a voice break, which is the abrupt shift between the two registers that creates the yodel sound that is often heard in early hillbilly country and that heavily influenced Bill Monroe when he was first creating his bluegrass singing style. ${ }^{95}$

In the verse, Obsorne drops down and sings around the first passagio, passing back and forth between his chest voice and head voice. In the first phrase, his voice has a darker, fuller tone, which shows clear contrast with the next phrase, in which he jumps up a fifth from B3 to F4. In this second phrase it is interesting to note that in measure 15, Osborne's voice flips up in a break, not as as result of encountering the passagio, but as a stylistic choice.

Bobby Osborne's performance in "Bluegrass Express” bears some similarities to Bill Monroe's performance in "Working on a Building" and "In the Pines." Most notably, he frequently uses the voice breaking technique, in spite of the fact that the song has a very different poetic tone and pace, reinforcing the assertion that the voice break is not specifically tied to an expression of grief, but instead an expression of any extreme emotion. ${ }^{96}$ Osborne uses the technique at instances when the melodic phrase is either ascending, like in mm. 19 or at its peak, such as in mm. 15. This gives the added effect of seemingly youthful excitement. The only time the break is used in a descending line is on the lyric "I'm goin' home," which is the emotional climax of the song, and Osborne uses the break on both the first and third word, giving added emphasis.

\footnotetext{
${ }^{95}$ Neal, Jimmie Rodgers, 57.

${ }^{96}$ Huron and Paul, "Breaking Voice," 31.
} 
In addition to the breaks, Osborne's performance resembles Monroe's in his use of scooping, though Osborne uses the technique far more frequently than Monroe. There is really only one phrase in the entire song where Osborne does not use any scooping, mm. 13-14, and this could be to reinforce the contrast between the chorus and the beginning of the verse. The scooping gives a feeling of excitement and eagerness, especially in tandem with the voice breaks. This could also have been a result of outside musical influences, since scooping is more commonly heard in commercial pop and country music. There is one instance in $\mathrm{m}$. 18 where Osborne uses a drop off similar to Monroe's, but is not heard again in the recording. Similar to the way that Monroe uses aspirated onsets in "In the Pines," there are a few instances where Osborne uses a glottal onset when singing the word "on," seen in mm. 31 and 53. A glottal onset is where the breath being used opens the vocal chords abruptly, creating a pressed, abrupt start to a vocal line, which, in this context, gives a sense of urgency. ${ }^{97}$

Between the three performers there is a clear consistency of style. This is not surprising, as they were all active during the same years and familiar with each other's styles. Between his own two recordings, separated by nine years, Monroe's own performance style is not much different. Both recordings were made relatively early in his career when he had his full vocal range. Bobby Osborne, who grew up hearing Monroe sing, closely imitates his high-pitched focused tone. Osborne also sings straight-tone, without any vibrato, like Monroe and many other early male bluegrass singers who performed in the rural belter style. While Stanley's performance sits in a lower register, he still uses the same kind of rhythmic accents as Monroe, which gives it the same muscled, angular character, as well as the straight-tone belt. In these early years, most bluegrass performers stuck closely to the performance style presented by

\footnotetext{
${ }^{97}$ Davids and LaTour, Vocal Technique, 53.
} 
Monroe in order to make it distinctly clear that they were playing bluegrass and not another kind of "mountain music." 


\section{Chapter 3: Analysis of Contemporary Female Performances}

The four female performers I have chosen for this study each come from a different musical background, but all have arrived at bluegrass. The analysis of these four recordings highlights how each performer brings her own musical experience into the recording, creating four different interpretations of what bluegrass can sound like. The four performances range from traditional to unconventional, and together they present a wide range of styles that have been used in contemporary bluegrass singing over the last fifteen years.

\section{"In the Pines"}

Celia Woodsmith of Della Mae did not always consider herself a bluegrass singer. Originally from Vermont, she came up playing a variety of styles, from rock and roll to country, and has taken influence from artists such as Bonnie Raitt and John Prine. ${ }^{98}$ Before forming Della Mae, Woodsmith performed in a roots rock duo in college and gained some notoriety as a guitarist and vocalist by playing festivals and opening for national acts, such as Taj Mahal and Leon Russell. She never received any formal vocal training and instead shaped her sound and technique while touring. The song "In the Pines" was recorded for their first EP, simply titled “Acoustic EP," which was released in 2010. The vocal arrangement is a tradition duo voicing, with one lead vocal, which Woodsmith sings throughout the entire recording, and a tenor chiming in on the choruses.

In Della Mae's recording of "In the Pines," Woodsmith sings in the key of D minor with the melodic line ranging from $\mathrm{D} 4-\mathrm{A} 4$, with one instance where the melody reaches up to Bb4. This sits right in the middle of the comfortable female vocal range for both soprano and alto

98 "Biography," Della Mae, accessed October 22, 2016, http://dellamae.com/celia-woodsmith. 
voices. ${ }^{99}$ The melody, which is the same in both the verse and the chorus, moves back and forth through the range, frequently leaping in fourths and fifths, but always returning to the tonic at the end of the phrase, giving the line a sense of finality. In m. 19, Woodsmith momentarily bends the pitch upward to a $\mathrm{Bb} 4$, but that is the only time she extends past the range of a fifth. It is hard to say what voice type Woodsmith fits into based on this performance because this range is so easily accessible for most female singers. Though the D4 is at the bottom of a comfortable soprano range, someone with that voice type would not have any problem singing there.

In this recording, Celia Woodsmith sings in a mixed register for the entire song. With the bottom of her range at $\mathrm{D} 4$, she is still singing above the transition between the low register and mixed range. ${ }^{100}$ There are some slight timbral differences as she moves from the lower register transition up to A4, which is the typical transition point from mixed voice to head voice, but she does not ever fully switch to head voice. In terms of bluegrass singing, Woodsmith does not take a early-style approach, which favors a pushed, straight-tone quality. There is a lot of natural vibrato and relaxed lightness in her voice, which could be put under the "urban crooner" category, as described by Fred Bartenstein. ${ }^{101}$ Woodsmith could certainly have employed a yodel technique, particularly at the top of the performances range around A4, but she chose not to. It would be appropriate to say that she is using more of an Mx2 voice mix overall, as her mix at the top of the range informs her mix on the descending lines, as in mm. 14-16. The Mx2 mix, which is used in the higher registers and allows for lower volume, supports Woodsmith's subdued performance.

\footnotetext{
${ }^{99}$ Julia Davids and Stephen LaTour, Vocal Technique: A Guide for Conductors, Teachers, and Singers (Long Grove: Waveland Press, 2012), 160.

${ }^{100}$ Davids and LaTour, Vocal Technique, 152.

${ }^{101}$ Fred Bartenstein, "Bluegrass Vocals," (working paper, Bartenstein and Bluegrass, Yellow Springs, 2010), http://www.fredbartenstein.com/bgvocals.html.
} 
In this rendition of "In the Pines," Woodsmith does not entirely stay in the bluegrass box, likely taking notes from rock versions of the song, such as the version recorded by Nirvana under the title "Where Did You Sleep Last Night?" in 1994. ${ }^{102}$ She sings in an urban crooner style, foregoing the straight-tone belt that is used by some artists to emulate the early bluegrass sound. Woodsmith's vibrato makes hear singing feel heavier, bringing to mind the Leadbelly recordings of the song from 1944. ${ }^{103}$ The mode itself, D minor instead of a major key, is a stylistic choice and changes the tone of the song, thanks to the contemporary Western association of the minor mode with gloom and sadness. ${ }^{104}$

In this same vein, Woodsmith plays with melodic structure, using chromaticism to create an uneasy, gloomy feel. She deploys this chromatiscism slightly differently in each verse. In the first verse, there is only one instance. In m. 19, Woodsmith plaintively sings the neighbor tone B4 on the phrase "What have I done?" In the second verse, there is much more chromaticism, both in $\mathrm{m} .59$ and $\mathrm{mm} .62-63$. In the third verse, there is just one more instance in $\mathrm{m} .75$, similar to the descending lines in the previous verse. Woodsmith also uses rhythm to create structural variety. The song is a waltz with a swung triplet feel, so Woodsmith's use of duplets in the second half of the song creates some contrast, which can be heard at mm. 62, 68, 75, and 94.

\footnotetext{
102 "Nirvana: MTV Unplugged in New York," Discogs, Accessed October 29, 2016, https://www.discogs.com/Nirvana-MTV-Unplugged-In-New-York/release/375980.

${ }^{103}$ Eric Weisbard, "A Simple Song that Lives Beyond Time," The New York Times, November 13, 1944, http://www.nytimes.com/1994/11/13/arts/pop-music-a-simple-song-that-lives-beyondtime.html?pagewanted=1.

${ }^{104}$ David Huron, "A Comparison of Average Pitch Height and Interval Size in Major- and Minor-key Themes: Evidence Consistent with Affect-Related Pitch Prosody, "Empirical Musicology Review 5, no. 2 (2008): 59.
} 
Vocally, Woodsmith uses heavy scooping on most of the notes, though it is unclear whether this is an unconsidered default or simply a stylistic choice. There is also one moment that sticks out in $\mathrm{m} .59$ where Woodsmith uses a chromatic turn that makes one think of a mournful weeping. At the end of the piece, on the last repeat of the words "cold winds blow," the meter suddenly shifts to a $4 / 4$ feel and slows dramatically. There is a full lift before Woodsmith finishes on the word "blow," on which she sings a short melisma that mimics the sound of the wind blowing.

\section{"Working on a Building"}

Patty Loveless is not commonly associated with the bluegrass scene, but she certainly has roots in the culture. Loveless grew up in Pikeville, Kentucky as a bona fide coal miner's daughter and spent her early life listening to bluegrass. She took to playing music and singing after having to move to Louisville, because her father had come down with black lung and needed treatment. Just a few years later, she was playing out with her brother at jamborees and made her first trip to Nashville at the young age of fourteen. ${ }^{105}$ After becoming the protégé of Porter Wagoner and Dolly Parton, she quickly moved up in the country scene. She became a regular on Billboard's country Top Ten starting in 1988, with two number-one singles in her first

five years as a solo artist. ${ }^{106}$ It was not until the early 2000s, after several years of a sales slump on new albums, that she decided to look back to her roots for inspiration. Loveless released her first bluegrass album, Mountain Soul, in 2001, directly following the success of the recent cult film hit, O Brother, Where Art Thou?, released in 2000, which had sparked a renewed interest in

${ }^{105}$ Steve Huey, "Patty Loveless: Biography," Allmusic, accessed October 22, 2016, http://www.allmusic.com/artist/patty-loveless-mn0000019241/biography.

${ }^{106}$ Huey, "Patty Loveless." 
American heritage music. ${ }^{107}$ Loveless was not the only artist inspired by the film to explore country music's Appalachian roots. ${ }^{108}$ At the time of the film's release, there was already a trend of renewed interest in American roots music, and her mentor, Dolly Parton, had released a bluegrass album in $1998 .{ }^{109}$ It did very well, and Loveless followed up with a bluegrass Christmas album, as well as two bluegrass-influenced country albums, before coming back with Mountain Soul II, which boasted a heavy dose of bluegrass while also exploring other Appalachian singing styles, particularly in gospel songs. ${ }^{110}$

In this gospel standard, Loveless sings in the original key of A major, the melody ranging from A3-C5. This is the exact span of the comfortable vocal range for an untrained alto. ${ }^{111}$ It is likely that Loveless could be classified as a mezzo soprano, because she has a very full sound down at the bottom of this recording's range. This song is performed as a standard bluegrass trio, with a high tenor (sung by Loveless), the melody in the lead voice, and a baritone at the bottom of the arrangement. Because Loveless is singing the tenor, she is often singing at the top of the range, but the melody is full of leaps, sometimes a full octave, so the low end of the range is still often heard. Most of Loveless's part is sung within the octave of A3-A4, but she briefly jumps up to the $\mathrm{C} 5$ during the chorus, as can be seen in $\mathrm{m} .22$.

\footnotetext{
${ }^{107}$ Huey, "Patty Loveless."

${ }^{108}$ Dick Weissman, Which Side Are You On?: An Inside History of the Folk Music Revival in America (New York: Continuum, 2005), 14.

${ }^{109}$ James Sullivan, "'O Brother' Inspires Bluegrass Boom / T Bone Burnett's Old-Timey Soundtrack Album a Surprise Hit," SFGate, March 7, 2002, http://www.sfgate.com/entertainment/article/O-Brother-inspires-bluegrass-boom-T-Bone2866744.php.

110 "Patty Loveless Plans Mountain Soul II for September Release," CMT News, last updated July, 2009, http://www.cmt.com/news/1615536/patty-loveless-plans-mountain-soul-ii-forseptember-release/.

${ }^{111}$ Davids and LaTour, Vocal Technique, 160.
} 
Patty Loveless's "Working on a Building," is performed in a "rural belter" style, which is more in line with the early bluegrass singing style. For most of the recording, she uses a heavy Mx1 low-voice mix, which is occurs in the lower registers and allows for higher volumes, and it can especially be heard when Loveless is belting at the top of the range. ${ }^{112}$ Loveless does occasionally pass through the lower register shift, typically located around C4-E4. This occurs primarily at the ends of phrases, which end on the tonic, A3. In the style of the rural belter, Loveless allows for a more noticeable shift between registers. She does this at the top end of the range as well. Loveless makes frequent use of the voice breaking technique, which, for women, is a brief and abrupt shift between the mixed middle range and head voice. This is a much more deliberate choice for women, who often have an easier time producing a seamless transition between the two. ${ }^{113}$ The technique can even be difficult for female singers who have received formal training, since Western classical vocal pedagogy favors a more seamless transition. There is one instance in this recording where Loveless lingers in the head voice for a full beat at $\mathrm{mm}$. 96-97. Here she employs a clear yodel technique, with a hard, abrupt shift between the mixed voice and head voice, and then returns back to the mixed chest.

In this recording, Patty Loveless is paying homage to early and traditional performance practices, bluegrass and older. Her dotted rhythms suggest the muscular, driven performances of the Bill Monroe or Ralph Stanley. Performing in the Bill Monroe key of A, Loveless sings in the rural belter style with no vibrato and a very bright, high belt. ${ }^{114}$ This is made even more prominent by Loveless's nod to the old Appalachian ballad technique where singers would

${ }^{112}$ Davids and LaTour, Vocal Technique, 160.

113 avids and LaTour, Vocal Technique, 151.

${ }^{114}$ Bartenstein, "Bluegrass Vocals." 
spontaneously hold notes for an undetermined amount of time. ${ }^{115}$ Loveless employs this technique at the beginning of each verse on the word "I," seen in mm. 2-4, 48-51, and mm. 9497. Of course, these ballad singers would often be singing unaccompanied, and Loveless was recording in a studio with a full band, so the lengths of her extended notes were likely predetermined. Even so, it gives a similar affect. Loveless also builds on this device by adding an extra bar to the sustained note, which retains some of that spontaneous uncertainty for the listener. On the last sustained note, Loveless adds another surprise by flipping up to the head voice from the $\mathrm{A} 4$ to the $\mathrm{C} 5$, employing the yodel technique.

Loveless uses a substantial amount of voice breaking, another homage to the old style of singing, and she does it in a couple different ways. The most obvious is the yodel technique used in m. 96, but she more frequently uses the quick voice break, briefly entering into head voice and then returning to mixed voice. Loveless uses this technique in two different ways. The first, which is more commonly found, is in the middle of the phrase, as in $\mathrm{mm} .51$ or 58 . The second is found at the end of phrases on the cut off of a word. This can be heard in the very first phrase, coming off of the word "sinner" in m. 5. Loveless adds a shadow vowel, which is "an emphatic 'uh' or 'ah' at the end of a final consonant," while flipping into head voice, which makes the phrase sound desperate and emphatic. ${ }^{116}$ Like Woodsmith, Loveless also uses a fair amount of scooping, but seems to have more control of when she does and does not use it. For example, in m.17, she scoops on the first A4 quarter note, but her attack on the second is right on the note. She also selectively uses a slide between notes, as can be heard individually in $\mathrm{m}$. 55 , as well as multiple times in a phrase, like in $\mathrm{m}$. 5. She also has two moments in the song where she adds a

${ }^{115}$ Travis D. Stimeling, The Country Music Reader, (New York: Oxford University Press, 2014), 14.

${ }^{116}$ Davids and LaTour, Vocal Technique, 116. 
vocable as an added emotional emphasis, the first in $\mathrm{mm} .70-71$, the second at the end in $\mathrm{m} .117$.

Overall, there is a variety of ornamental expression that conveys an earnest excitement, and a clear sense of development in her choices from verse to verse.

\section{"Pretty Polly"}

Abigail Washburn had a unique entry into the bluegrass world. Before picking up a banjo she had dreams of being a lawyer, with a special interest in international relations with China. It was during her time there that she became interested in using music to bridge the gap between the American and Chinese cultures. ${ }^{117}$ While she had already been singing for her entire life, it was the purchase of a banjo that set her down the path of bluegrass and folk, and she became known for her unique brand of diplomacy, having traveled and toured in China multiple times, as well as her fresh, globalized approach to American heritage music. Vocally, she spent time in her early adulthood singing back-up in different bands, but did not take the lead until she was asked to fill in as banjo player on tour for her friends' band, The Cleary Brothers. Defying labels, Washburn has played in a variety of bands, including Uncle Earl, an "all g'earl” old-time group; the Sparrow Quartet, who were sponsored by the United States government to tour in China; as well as touring and recording with her banjo-playing husband, Béla Fleck. ${ }^{118}$ Washburn's interpretation of the traditional ballad, "Pretty Polly," can be found on the eponymous album she recorded with Fleck, Béla Fleck \& Abigail Washburn, which was released in 2014.

\footnotetext{
117 Abigail Washburn, Abigail Washburn: Building US-China Relations...By Banjo, Video, 6:34, February 2012, https://www.ted.com/talks/abigail washburn building us china relations by banjo/transcript?1 anguage $=$ en.

${ }^{118}$ David Jeffries, "Abigail Washburn: Biography," Allmusic, accessed October 22, 2016, http://www.allmusic.com/artist/abigail-washburn-mn0000776618/biography.
} 
Washburn's interpretation of Pretty Polly covers an impressive range, spanning F3-D5, very nearly a full two octaves, the widest range of all the recordings in this study. While the top of the range is close to being within the comfortable range for an amateur alto, the bottom drops a major third below what would be commonly expected, and is in fact closer to the bottom of an amateur tenor range. ${ }^{119}$ Most of her singing occurs below the staff, the exception being the second line in every three-line phrase, where there is a leap from B3 to A4, the higher line ranging $\mathrm{B} 3-\mathrm{A} 4$. The other two lines have a tessitura that centers around the tonic of $\mathrm{Bb}$, working in a range of F3-D4.

Washburn, with the widest range of all the singers, moves through her register shifts more frequently than anyone else in the study. The first and second phrases of the three-line stanza sit mostly in the low register, going no higher than E4. While there's no abrupt shift from the low voice to the low Mx1 mix, there is a change in the color of her tone, brightening as it ascends, particularly around D4 and up. In the middle phrase, the tone brightens even more, but still has natural vibrato without any pressing, suggesting more head voice in the mix. Going no higher than A4 in the principal melody, Washburn could reasonably stay in this mix through the whole song, but instead she uses her head voice to bring contrast to the vocal line. She employs a yodel technique similar to what Loveless used in her recording, a style that was very popular in early country, and can often still be heard in contemporary country music. ${ }^{120}$ For example, in m. 9, she sings in Mx2 mixed voice, except for on the B4, where she flips into head voice with a noticeably hard shift, creating a slight glottal sound. She does this in all verses except one, where she is imitating the voice of the male character, Willie. She also uses a yodel register shift in the

${ }^{119}$ Davids and LaTour, Vocal Technique, 160.

${ }^{120}$ Timothy E. Wise, Yodeling and Meaning in American Music (American Made Music Series) (Jackson: University Press of Mississippi, 2016), Kindle Edition, Ch. 1. 
“Oh, pretty Polly" interlude in mm. 110-131, flipping up on the word "Polly." Because she is able to stay in mixed voice in $\mathrm{m} .86$, it is apparent that this yodel is a stylistic choice and not a result of her mixed range's limitations. Washburn's stylistic choices are rooted in the traditional Appalachian performance practice, but she brings a modern perspective. Her haunting rendition of "Pretty Polly" is more introspective than a traditional ballad performance, but is also done with minimal accompaniment, just twin banjos, assisted by her husband, Béla Fleck. It is interesting to note that during the interlude in mm. 107-109, a brief phrase from the Appalachian fiddle tune "Cluck Old Hen" is played, further aligning the rendition with the older Appalachian versions of the ballad. Washburn's tone is subdued and breathy, but she performs the ballad mostly straight-tone. She uses her vibrato selectively, only when she is voicing the characters in the story. For example, when Polly is expressing concern to Willie in the second verse, Washburn uses vibrato on the second, longer syllable of "Willie" in m. 37 and again on the repeat in $\mathrm{m} .42$. In the same phrase, she also uses the vibrato on the word "afraid," poetically the most important word in the verse. She uses vibrato one other time in the recording when she is voicing Willie in $\mathrm{m} .86$ as he is confirming that he is indeed going to kill Polly. In all these instances, the vibrato is used to give a sense of heightened expression of negative emotion, whether it be fear or malice.

Washburn uses simple, even rhythmic patterns, rarely using any dotted rhythms beyond what suits the text. This steadiness of rhythm helps the introspective mood that Washburn wants, and suggest a walking pace, helping one imagine Willie and Polly plodding through the woods. To reinforce these rhythmic patterns, Washburn is also very precise with her cutoffs, and at times uses a vocal break to reinforce the cutoff with a shadow vowel. ${ }^{121}$ She uses the voice breaks in a

${ }^{121}$ Davids and LaTour, Vocal Technique, 116. 
couple other ways as well. The first is the previously mentioned register shift, acting as a brief yodel, where Washburn flips up in each verse on the B4, as is seen in $\mathrm{m}$. 9. It is actually the absence of the voice break in $\mathrm{m} .86$ that stands out to the listener who is expecting it. As a result, the line is given a more forceful, perhaps violent character, fitting for a confession of murderous intent. Otherwise, a voice break is placed in the middle of a descending leap, seen in mm. 98-99. Here, Washburn uses the break in the phrase "stabbed her in the heart," and the break suggests the swift stabbing motion of the knife, with the break happening right before the word "heart." Here, she also sings that same word with a pressed tone and no scooping, further conveying the harsh nature of the text. Washburn also takes an artistic liberty with the arrangement and adds a lamenting interlude, singing the phrase, “oh, Pretty Polly" four times, each time ending on a higher note. Perhaps that is the sound of Polly's soul ascending to heaven.

\section{"Bluegrass Express"}

Of the four women, Rhonda Vincent has had the longest tenure in the bluegrass world. She began playing with her family's band at the young age of five years and quickly became an accomplished instrumentalist and vocalist, playing both fiddle and mandolin. ${ }^{122}$ In her midtwenties, Vincent started playing out on her own, choosing to primarily play mandolin in addition to singing. Under her first recording contract with Rebel Records, she recorded several albums that straddled the dividing line between bluegrass and country music, which was in line with her musical upbringing. She signed with Giant, a major Nashville label, in the mid-1990s

\footnotetext{
${ }^{122}$ Zac Johnson, "Rhonda Vincent: Biography," Allmusic, Accessed October 22, 2016, http://www.allmusic.com/artist/rhonda-vincent-mn0000472735/biography.
} 
and recorded two full-blown contemporary country albums before she decided to fully commit to playing and recording bluegrass, putting out the aptly titled Back Home Again in $2000 .^{123}$

Vincent's recording of the Osborne Brothers' song "Bluegrass Express" appeared in 2001 on her second bluegrass album, The Storm Still Rages, which also marked the debut of her newly assembled backing band, The Rage. Recorded in the original tenor lead arrangement, Vincent sings in the key of F major, with the melody ranging A3-D5. While the tessitura of this song, centered around A4, still sits in a comfortable mid-range, Vincent has no difficulties navigating and often sings with a generally higher tessitura than is heard from rural belters. She saves the highest note for the very end, a subtle cadenza in the tag of the last line.

Vincent takes a similar approach in her performance of "Bluegrass Express." With the highest tessitura of all the female performances in this study, it is difficult to identify where her natural register shifts fall, because she is able to sing in a high mix well beyond the expected transition. It is likely that she has a naturally high soprano voice, because she seems to sing in mix above C5 with little difficulty, and apart from the very subtle voice breaks in the verse, there aren't any instances in the recording where she completely flips into head voice. There is a clear difference between her mixes in the verse and the chorus, because her tone thins and brightens noticeably when she sings above A4. There are also two instances where she passes briefly into chest voice, occurring in the verse at $\mathrm{mm} .13$ and 79. Singing with absolute straight-tone, Vincent has the purest performance of the rural belt style. ${ }^{124}$

Vincent also sings in the traditional style of a rural belter, singing with a bright, ringing tone and absolutely no vibrato. However, she used the scooping technique more than any other

\footnotetext{
123 Johnson, "Rhonda Vincent."

${ }^{124}$ Bartenstein, "Bluegrass Vocals."
} 
artist in the study. As can be seen in the score markings, it is constant throughout the recording. The scoop gives a sound of sincere eagerness, which is fitting with the text, which talks about returning home by train. She very sparingly uses the vocal break technique, and what can be heard is subtle. It is only heard in the verse at the same spot each time, seen in mm. 17-18 and mm. 83-84. Used on the phrase, "Richmond, Winchester, Bowling Green," it is used to convey building excitement as they get closer and closer to home. It is a very subtle break, resulting in a whine-like, plaintive quality. Her use of drop-offs, as seen in $\mathrm{m}$. 18, also aids in creating that effect. On the very last chorus Vincent adds a few extra ornaments on the operative phrase "I'm going home," including a slide up from B4 to C5 on "I'm," as well as a quick turn on the word "home." On the repeat in the tag Vincent slides even higher to D5, serving as the melodic climax of the song.

Analysis of these four recordings show that, while each female performer has their own distinct style, there is a common usage of certain stylistic devices, particularly voice breaking and scooping. All female performers except for Woodsmith use the voice break technique, with Washburn relying upon this technique most heavily. However, Woodsmith is the one who uses a vocal scoop the most, with Vincent close behind, and Washburn does not use the technique at all. While all of the contemporary female performers draw upon early bluegrass singing techniques, they do not necessarily use all of the, and each approaches the techniques differently. This further suggests that, while there may be a core set of techniques that are associated with the bluegrass style, a singer does not have to use all of them in order to be performing in the style, but instead can choose which ones fit with his or her interpretation. Woodsmith and Washburn both have more unconventional bluegrass singing styles, but they come from very different stylistic backgrounds, and their performances of the bluegrass songs differ greatly. Loveless and 
Vincent both follow the traditional bluegrass style of the original early male singers much more closely, and they instead use the arrangements of the songs as a way of creating a unique performance, which will be further discussed in the next chapter. Still, they are all bluegrass performers. 


\section{Chapter 4 - Comparison of Traditional Male and Contemporary Female Performances}

Between the two groups in this study, there are about as many similarities as there are differences. The recordings are separated by no fewer than thirty-seven years, and in that time many new music genres and cultures have appeared. While the women included in this study were certainly influenced by the men in this study who came before them, there were also many other artists and performance styles that also had an impact upon the way they recorded these songs. Each artist who performs or records a song becomes a part of that song's path through time. It wasn't until recently, largely thanks to the efforts of Murphy Hicks Henry, that women became more visible in the timelines of these songs. The aim of this study is not to say whether one group of performers is better than the other, but instead is an attempt to broaden the definition of the bluegrass vocal style. Therefore, with these comparisons, the question is not so much "better or worse?," but instead "What is different?" or "What do they have in common?" To further illustrate the differences in arrangement and lyrics, I have included a color-coded table of both versions side by side. I have also underlined the text that differs from the other version in both sets of lyrics.

With "In the Pines," the two performances are significantly different from each other. In

the Della Mae version, Celia Woodsmith sings the lead and is only accompanied by harmony on the chorus, whereas Bill Monroe sings the tenor in all sections, creating a very different texture. Woodsmith also chooses to sing the song in a minor key, and includes some descending chromatic lines. In Western music, descending lines are often associated with negative feelings 
like sadness, and it has the same effect here. ${ }^{125}$. In terms of singing style, Bill Monroe performs in the classic "rural belt" style, characterized by his pressed, straight-toned delivery, with his pronunciation of the text reflecting a rural upbringing. Contrastingly, Woodsmith sings in an "urban crooner" style, using full vibrato, extensive vocal inflection, and a pronunciation that would suggest a non-rural cultural background and/or the influence of other popular styles of vocal performance, particularly blues and rock. ${ }^{126}$

In terms of vocal ornaments, there is very little in common between the two.

Woodsmith's background in folk and rock shows in her scooping and use of vibrato, but her use of turns and the ritardando ending, which Monroe also uses in his recording, certainly fall under the umbrella of bluegrass technique. While Monroe does use embellishments in his vocal lines, there is a more precise, angular character to his performance, as if each slide and drop-off were premeditated and rehearsed. Woodsmith's performance has much more rhythmic variation, and it is clear that she is drawing influence from outside the bluegrass style, perhaps drawing from the older Leadbelly recordings of the song, or the more recent Nirvana recording from 1994. Another major difference is that Woodsmith did not include the "blowing wind" interlude and instead includes another sixteen-bar instrumental break. However, she does still use some subtle text painting to imitate the sound of wind at the end in mm. 120-121.

There is also a notable difference in how the two bands arrange the lyrics. While both recordings use the same verses, they are arranged differently with the choruses. As can be seen in

\footnotetext{
${ }^{125}$ William G. Collier and Timothy L. Hubbard, "Musical Scales and Evaluations of Happiness and Awkwardness: Effects of Pitch, Direction, and Scale Mode," The American Journal of Psychology 114, no. 3 (2001): 371.

${ }^{126}$ Fred Bartenstein, "Bluegrass Vocals," (working paper, Bartenstein and Bluegrass, Yellow Springs, 2010), http://www.fredbartenstein.com/bgvocals.html.
} 
the table below, Monroe's arrangement is fairly straightforward, using the same pattern of versechorus-interlude each time with two 8-bar instrumental breaks. In contrast, Della Mae's arrangement is less straightforward. The beginning two choruses follow a slow-tempo introduction, and then the first verse is followed by just one chorus and an 8-bar break. The second half of the song is doubled up, with two verses followed by two choruses and a 16-bar instrumental break. At the end there is one more chorus, which functions like a delayed tag. There are also word differences which slightly change the tone of each verse. For example, in the last line of the "little girl" verse, Monroe sings "cause me to leave," whereas Woodsmith sings "have caused me to lose." These are different verbs and tenses with distinctly different implications. The former suggests that the male character has a tendency to leave his home of his own volition, whereas the latter suggests that the woman in the story had control over an event that has transpired which caused the man to lose his home. As a result, there is a distinctly different power balance between the two genders presented in each version of this song. In the "captain" verse, Woodsmith adds two words on to the beginning of the third line, but they are fairly inconsequential. The interesting and questionable choice that she made in this verse was to pronounce the work "asked" as "aksed," with the /k/ consonant coming before the /s/. This is a pronunciation found in African American Vernacular English, and one that has historically been a point of contention in American culture, some asserting that the use of this pronunciation is closely tied to Black American Identity. ${ }^{127}$ As an upper-middle class white woman from Vermont, Woodsmith's use of this pronunciation comes off as culturally appropriative, and the choice does not seem justified. In the third verse, the only difference is

\footnotetext{
127 John McWhorter, "The 'Ax' Versus 'Ask' Question," Los Angeles Times, January 19, 2014, http://articles.latimes.com/2014/jan/19/opinion/la-oe-mcwhorter-black-speech-ax-20140119.
} 
that Woodsmith omits the "and" at the beginning of the last line. This creates some slight rhythmic variation, but poetically does not change anything.

Table 1. Comparison of lyrics for the Monroe and Woodsmith recordings of "In the Pines."

\begin{tabular}{|c|c|}
\hline Bill Monroe & Celia Woodsmith \\
\hline $\begin{array}{l}\mathbf{1 / 2} \text { Vocal Interlude } \\
\text { Verse } \mathbf{1} \\
\text { The longest train I ever saw } \\
\text { Went down that Georgia Line. } \\
\text { The engine passed at six o'clock } \\
\text { And the cab passed by at nine. } \\
\text { Chorus } \\
\text { In the pines, in the pines } \\
\text { Where the sun never shines } \\
\text { And we shiver when the cold winds blow } \\
\text { Vocal Interlude } \\
\text { 8-bar Instrumental Break } \\
\text { Verse } 2 \\
\text { I asked my captain for the time of day } \\
\text { He said he throwed his watch away } \\
\text { A long steel rail and a short cross-tie } \\
\text { I'm on my way back home. } \\
\text { Chorus } \\
\text { Vocal Interlude } \\
\text { 8-bar Instrumental Break } \\
\text { Verse } 3 \\
\text { Little girl, little girl, what have I done } \\
\text { To make you treat me so? } \\
\text { You cause me to weep, you cause me to mourn } \\
\text { You cause me to leave my home. } \\
\text { Chorus } \\
\text { Vocal Interlude }\end{array}$ & $\begin{array}{l}\text { Chorus } \\
\text { In the pines, in the pines } \\
\text { Where the sun never shines } \\
\text { And you shiver when the cold winds blow. } \\
\text { Chorus } \\
\text { Verse } 1 \\
\text { Little girl, little girl, what have I done } \\
\text { To make you treat me so? } \\
\text { You have caused me to weep, } \\
\text { you have caused me to mourn } \\
\text { You've caused me to lose my home. } \\
\text { Chorus } \\
\text { 8-bar Instrumental Break } \\
\text { Verse } 2 \\
\text { The longest train I ever saw } \\
\text { Went down that Georgia line. } \\
\text { The engine passed at six o'clock } \\
\text { The cab went by at nine. } \\
\text { Verse } 3 \\
\text { I ak'sed my captain for the time of day } \\
\text { He said he throwed his watch away } \\
\text { It's a long steel rain and a short cross tie } \\
\text { I'm on my way back home } \\
\text { Chorus } \\
\text { Chorus }\end{array}$ \\
\hline
\end{tabular}




\section{"Working on a Building"}

Between the two recordings of "Working on a Building," there are considerably more similarities. Bill Monroe and Patty Loveless both perform in the rural belter style, neither one using vibrato and using a very forward, bright tone in their upper registers. ${ }^{128}$ Interestingly, they both recorded the song in the key of A major, and Loveless sings all the same parts that Monroe sang. While the notes are the same, they sound very different in each performer's voice, because of where the vocal lines sit in each singer's vocal range. In the phrases where Monroe is using his falsetto, Loveless is using her mixed voice. Monroe and Loveless do use some of the same stylistic devices, such as slides and quick dotted rhythms, and Loveless even imitates Monroe's inflection and slide on the word "do," seen in m. 21 (Monroe) and m. 55 (Loveless). The most noticeable difference in terms of stylistic devices is Loveless' use of vocal breaks, which Monroe does not use, being that he sings in falsetto for most of the recording. Loveless, who does not have the falsetto range, instead uses the voice breaks and yodel to recreate the traditional bluegrass vocal sound. The vocal breaks also add a dramatic eagerness to Loveless's singing. Loveless' choice in extending the word "I" in each verse also adds to the dramatic build of the song, an element that is missing in the Monroe version. This is most readily apparent in her arrangement of the song, which is close to Monroe's, but with some tweaks. Instead of beginning on the chorus like Monroe, she goes straight into the first verse. She also adds an extra bar after the first phrase--"If I was a preacher"--allowing for a quick guitar fill, which she does again in subsequent verses. However, the choruses are performed the same as they are in the Monroe version, and the Loveless version has two six-bar instrumental breaks, also like Monroe's. Both versions have very similar endings, sung a capella with a ritardando, as well as full lifts between

${ }^{128}$ Bartenstein, "Bluegrass Vocals." 
each word. Lyrically, almost everything is the same except for the first verse, where Loveless sings “sinner” instead of Monroe’s “gambler.” Because Loveless uses more stylistic variation that develops through the song, her version more clearly communicates the excitement of the lyrics.

Table 2. Comparison of lyrics for the Monroe and Loveless recordings of "I'm Working on a Building."

\begin{tabular}{|c|c|}
\hline Bill Monroe & Patty Loveless \\
\hline $\begin{array}{l}\text { Chorus } \\
\text { I'm workin' on a building } \\
\text { I'm workin' on a building } \\
\text { I'm workin' on a building } \\
\text { For my Lord, for my Lord } \\
\text { It's a Holy Ghost building } \\
\text { It's a Holy Ghost Building } \\
\text { It's a Holy Ghost building } \\
\text { For my Lord, for my Lord } \\
\text { Verse } 1 \\
\text { If I was a gambler } \\
\text { I tell you what I would do } \\
\text { I'd quit my gamblin' } \\
\text { And I'd work on a building, too } \\
\text { Chorus }\end{array}$ & $\begin{array}{l}\text { Verse } 1 \\
\text { If I was a sinner } \\
\text { I'll tell you what I'd do } \\
\text { I'd quit my sinnin' } \\
\text { And I'd work on a building, too } \\
\text { Chorus } \\
\text { I'm working on a building } \\
\text { I'm working on a building } \\
\text { I'm working on a building } \\
\text { For my Lord, for my Lord } \\
\text { It's a Holy Ghost building } \\
\text { It's a Holy Ghost building } \\
\text { It's a Holy Ghost building } \\
\text { For my Lord, for my Lord! }\end{array}$ \\
\hline 16-bar Instrumental Break & 16-bar Instrumental break \\
\hline $\begin{array}{l}\text { Verse } 2 \\
\text { If I was a drunkard } \\
\text { I tell you what I would do } \\
\text { I'd quit my drinkin' } \\
\text { And I'd work on a building, too } \\
\text { Chorus }\end{array}$ & $\begin{array}{l}\text { Verse } 2 \\
\text { If I was a drunkard } \\
\text { I tell you what I'd do } \\
\text { I'd quit my drinkin' } \\
\text { And I'd work on a building, too } \\
\text { Chorus }\end{array}$ \\
\hline 16-bar instrumental break & 16-bar Instrumental Break \\
\hline $\begin{array}{l}\text { Verse } 3 \\
\text { If I was a preacher, } \\
\text { I tell you what I would do } \\
\text { I'd keep on preachin' } \\
\text { And I'd work on the building, too } \\
\text { Chorus }\end{array}$ & $\begin{array}{l}\text { Verse } 3 \\
\text { If I was a preacher } \\
\text { I tell you what I'd do } \\
\text { I'd keep on preachin' } \\
\text { And I'd work on a building, too } \\
\text { Chorus }\end{array}$ \\
\hline
\end{tabular}




\section{"Bluegrass Express"}

The two versions of "Bluegrass Express" reveal the most similarities of all the pairs of recorded performances considered in this study. Rhonda Vincent sticks very closely to Bobby Osborne's vocal performance style, particularly his inflection and tone. They are both rural belters, and Rhonda Vincent's clear, bright tone matches Osborne's well. This is not terribly surprising, as Vincent did grow up singing traditional bluegrass. Another distinct similarity between their stylistic choices is both of their tendencies to scoop frequently, especially at the beginning of words. However, Vincent still scoops much more frequently than Osborne. For example, in the phrase "riding the Bluegrass Express," Osborne scoops on two syllables, seen in mm. 23-24, where Vincent scoops on four syllables, seen in mm. 23-24 of her version. Vincent also makes use of the slide technique, but not until the very end of her recording. She also uses a slight variation on the melody in the verse, singing an F\# on the second syllable of "Newport," where Osborne stays on the same pitch as the previous syllable.

The most notable difference between the two recordings is the arrangement. Vincent's recording is in the key of $\mathrm{F}$ major instead of the original $\mathrm{D}$ major, and it serves as an extended version of the Osborne recording. Where The Osborne Brothers have a playout, Rhonda Vincent includes a second sixteen-bar instrumental break, followed by a chorus-verse-chorus, and finishing with a tag. While there is almost twice as much lyrical and musical content, Vincent takes her recording at a faster tempo. Vincent's version does have more energy and excitement, thanks to a slightly faster tempo and more scooping, but the difference between the two versions is not profound. This perhaps is because the emotional content of the song text is not terribly complex, and does not have any story development or characters, as in "Pretty Polly." 
Table 3. Comparison of lyrics for the Osborne and Vincent recordings of "Bluegrass Express."

\begin{tabular}{|l|l|}
\hline Bobby Osborne & Rhonda Vincent \\
\hline Chorus & Chorus \\
Riding the Bluegrass Express & Riding the Bluegrass Express \\
Riding the Bluegrass Express & Riding the Bluegrass Express \\
This train will soon be gone & This train will soon be gone \\
And I'm going home & And I'm going home \\
On the Bluegrass Express & On the Bluegrass Express! \\
Verse & Verse \\
She'll cross the river at Newport Town & She'll cross the river at Newport Town \\
Louisville, Lexington, she's Southbound & Louisville, Lexington, she's Southbound \\
Richmond, Winchester, Bowling Green & Richmond, Winchester, Bowling Green \\
Prettiest place I've ever seen! & Prettiest place I've ever seen! \\
Chorus & Chorus \\
10-bar Instrumental Break & 10 -bar Instrumental Break \\
Chorus & Chorus \\
Playout & 10-bar Instrumental Break \\
& Chorus \\
& Verse \\
& Chorus \\
& Tag \\
& And I'm going home \\
& On the Bluegrass Express! \\
\hline
\end{tabular}

\section{"Pretty Polly"}

The two versions of "Pretty Polly" are the most different of any paired interpretations in this study. Washburn actually performs her version a half-step lower than Stanley, singing in Bflat major, Stanley singing in B major. Where Stanley is a rural belter, singing with a pressed, straight-tone belt Abigail Washburn is an urban crooner, and while she mostly sings straighttone, her vibrato still comes through at certain moments when it is suits the storytelling. Washburn also chose to perform "Pretty Polly" with a different variation of the melody than what Stanley chose. Because "Pretty Polly" is an old ballad, there have been many versions performed, and recordings of the song have existed since 1925, first set to record by John 
Hammond. ${ }^{129}$ Washburn's rendition brings to mind recordings made by early artists like E.C. Ball or Appalachian ballad singer Jean Ritchie, but the version is still her own. This creative freedom is one of the most fascinating parts of the ballad tradition, and it allows the songs to be remolded and reborn again and again as the years move forward.

This wide variation can also be seen in lyrics. The original English broadside ballad from which "Pretty Polly" descended had upwards of thirty verses, but very rarely are they all performed in one sitting. This would allow a performer to pick and choose which verses to include, so long as the story made sense, and it resulted in many variations of the same original song. Also, because many of these songs were learned through oral tradition over hundreds of years, wording of individual verses has also changed over time. For example, the "stabbing" verses in each of the versions studied here are significantly different. In the Stanley Brothers version, the first two lines describe Willie ripping open Polly's dress before stabbing her in the heart, which has a strong sexual overtone. In contrast, Washburn's stabbing verse only describes Polly falling into her grave after Willy stabs her. With this verse in articular, there is a clear gendered difference in the way the story is told. Washburn's closing verse is also entirely different and has a much clearer moralistic tone, which was common in the older Appalachian ballad performances. ${ }^{130}$ She chose to sing fewer verses, singing only seven where Stanley sings eleven, as can be seen in Table 4. Washburn starts singing at the "come go along with me" verse, which is the third verse in the Stanley version. In terms of the story, this does not take anything away, because the verse still mentions the prospect of marriage. She also omits the "grave" verse

${ }^{129}$ Paul Slade, Unprepared To Die: America's Greatest Murder Ballads And The True Crime Stories That Inspired Them (London: Soundcheck Books, 2015), 166.

${ }^{130}$ Encyclopedia of Appalachia, s.v. "Ballads," accessed October 22, 2016, http://www.encyclopediaofappalachia.com/entry.php?rec=31. 
and the "pleading" verse, which takes away some of the drama and suspense, but ultimately doesn't obstruct the continuity of the story.

While the pitch content of the two melodies is very similar, the rhythmic structures of each performance are different enough that the melodic shapes feel very different. Washburn uses even eighth note rhythms with carefully placed rests, which creates a flowing, rolling feel to the line. In contrast, Stanley uses many dotted rhythms and fast turns and runs, which gives the line an angular, muscular quality. While Stanley's hollering belt gives a driving, menacing character to the murderous tale, Washburn's hushed, breathy tone, combined with the yodel technique, makes it sound like she is telling a spooky ghost story. Washburn also engages more with the characters themselves by using her voice to differentiate their speech from the narration. She does this by using voice breaks to express Polly's fear and Willy's malice, as well as speechsinging the words "'bout right" in mm. 86-87, imitating the accent that Willy might have. Because of this and the vocal interlude lamenting Polly's demise, Washburn's rendition engages more fully with the darkness and drama of the story.

Table 4. Comparison of lyrics for the Stanley and Washburn recordings of "Pretty Polly."

\begin{tabular}{|c|c|}
\hline Ralph Stanley & Abigail Washburn \\
\hline Verse 1 & Verse 1 \\
\hline Oh, Polly, pretty Polly, would you take me unkind & Polly, pretty Polly come go along with me \\
\hline Polly, Pretty Polly, would you take me unkind & Polly, pretty Polly, go along with me \\
\hline Me to set beside you and tell you my mind & 'Fore we get married some pleasures to see \\
\hline $\begin{array}{ll}\text { Verse2 } \\
\end{array}$ & Verse 2 \\
\hline Well my mind is to marry and never to part & She climbed up behind him and away they did ride \\
\hline My mind is to marry, never to part & Climbed up behind him and away they did ride \\
\hline First time I saw you it wounded my heart & O'er the mountains to the other side \\
\hline 16-bar Instrumental Break & 4-bar Instrumental Interlude \\
\hline
\end{tabular}




\section{Verse 3}

Well, Polly, pretty Polly come and go along with me Polly, pretty Polly, come go along with me Before we get married, some pleasures we'll see

\section{Verse 4}

So he led her over mountains and valleys so deep He led her over mountains, dark valleys so deep

Polly mistrusted and then began to weep

\section{6-bar Instrumental Break}

Verse 5

Saying Willie, Little Willie I'm afraid of your ways

Willie, Little Willie, I'm afraid of your ways

The way you've been rambling, you lead me astray

Verse 6

Now, Polly, Pretty Polly, your guess is about right

Polly, pretty Polly, your guess is about right

I dug on your grave the biggest part of last night

\section{6-bar Instrumental Break}

Verse 7

Then he led her a little farther and what did she spy? He led her a little farther, what did she spy?

A new dug grave with a spade lying by

Verse 8

Then she knelt down before him a-pleading for her life

She knelt before him, pleading for her life

Let me be a single girl if I can't be your wife

Verse 9

Well, Polly, pretty Polly that never can be

Polly, Pretty Polly, that neve can be

Your past reputation's been trouble to me

\section{6-bar Instrumental Break}

\section{Verse 10}

Then he opened up her bosom as white as any snow He opened up her bosom, white as any snow

He stabbed her through the heart and the blood did overflow

Verse 11

Then he went down to the jailhouse and what did he say? He went to the jailhouse, what did he say?

I've killed Pretty Polly and I'm trying to get away

\section{Verse 3}

Willy, oh Willy I'm afraid of your ways

Willy, oh Willy, I'm afraid of your ways

I fear your intention to lead me astray

Verse 4

They rode o'er the mountains and valleys so deep

Rode o'er the mountains and valleys so deep

Soon pretty Polly, she began to weep

\section{4-bar Instrumental Break}

\section{Verse 5}

Polly, pretty Polly your guess is 'bout right Polly, pretty Polly, your guess is 'bout right I dug on your grave the better part of last night Verse 6

He stabbed her in the heart, her heart's blood it did flow Stabbed her in the heart, her heart's blood it did flow Into the grave pretty Polly did go

\section{4-bar Instrumental Interlude}

Vocal Interlude

Oh pretty Polly $x 4$

\section{6-bar Instrumental Interlude}

Verse 7

Well now gentlemen and ladies I bid you farewell Gentlemen and ladies, I bid you farewell For killing pretty Polly I soon will be in Hell 
With each paired male-female comparison in this study, there is a different balance of similarities and differences. At one end of the spectrum, Rhonda Vincent's performance of "Bluegrass Express" sounds and looks very closely similar to Bobby Osborne's performance. Of the two Bill Monroe songs, Patty Loveless sticks closer to the early male style of singing, where Celia Woodsmith opts for a blues- and rock-influenced interpretation of the song. Abigail Washburn and Ralph Stanley, informed by different traditions of performance practice, essentially recorded two very different variations of the same old ballad. Overall, the female performers, through use of arrangement, and vocal devices, pay closer attention to the emotional undertones of the songs and allow them to color their performances. 


\section{Chapter 5: Conclusion}

In this study, I transcribed and analyzed the vocal performances of four well-known bluegrass songs, each performed by both an early male bluegrass singer and a contemporary female bluegrass singer. From this research I hoped to gain insight into how the contemporary women performed these songs differently compared to the men, who demonstrate the traditional "high and lonesome" bluegrass sound. Being that it is a style firmly rooted in male singing and masculine expression, particularly the use of falsetto, I wanted to look at how the women performers used their female voices to perform in the bluegrass style, or if they decided to approach the material in an entirely different way. For both the men and the women, I examined their use of range, vocal register, and stylistic ornamentation and technique in order to better understand these differences. My second aim was to understand how these women performers engaged with the emotional content of the lyrics differently from the men, and whether they more outwardly expressed that emotional content through their stylistic vocal technique and structuring of the text.

The results of my analysis showed that almost all the women included in the study incorporated at least some elements of the traditional bluegrass vocal style, with Rhonda Vincent replicating the "high and lonesome" sound most closely. Celia Woodsmith's performance, while supported by traditional bluegrass instrumentation, did not resemble traditional bluegrass singing, instead suggesting a blues and rock influence. She frequently used vibrato, sang the entire performance in her mixed voice, and did not use the plaintive voice break technique which Bill Monroe uses in his performance. She also did not include the vocal interlude that Monroe uses in his arrangement, which shows off the higher register. 
With the exception of Woodsmith, all the women performers made ample use of their upper registers, though all with different balances of mixed voice and head voice. All but Woodsmith used the voice break technique, which is heard in every male recording except for Ralph Stanley's. Interestingly, Washburn, who is directly compared to Stanley, used the vocal breaks and register changes in her recording more than any other female performer in the study. In addition to the high belt and register switches to head voice, Rhonda Vincent and Patty Loveless also performed with a straight tone belt, which is another essential element of the traditional bluegrass sound and can be heard in all of the male bluegrass recordings in the study. While Abigail Washburn performed mostly with straight tone, she chose to use her vibrato as a stylistic device, accenting certain words that were poetically significant, which deviates from the traditional bluegrass style of singing, which Stanley observed more closely in his recording. Looking at the arrangement of the recordings, all the women chose to perform their songs differently than their male counterparts. While Vincent performed the verses and choruses almost identically to Osborne, she chose to add an additional instrumental break, verse, two choruses, and a tag to her recording. Similarly, Loveless mostly retains Monroe's arrangement, but alters it slightly by cutting a chorus and adding some extra bars to verses. In Washburn's recording of "Pretty Polly," Her most significant alteration is that she adds a new vocal interlude, which simply repeats the phrase, "Oh, Pretty Polly."

This vocal interlude that Washburn uses also holds significance in regard to my inquiry about engagement with the text. In my analysis of the male performances, I did find that they engaged one some level with the emotional content of the text. Two of the songs, "Working on a Building" and "Bluegrass Express," did not require much depth of interpretation, as they presented relatively basic sentiments of devotion and excitement, respectively. While the text of 
"Pretty Polly" presented a dramatic, violent story, Stanley's performance followed the older ballad performance practice of emotional neutrality, and the emotion of the story didn't reflect overtly in his performance. However, in Monroe's performance of "In the Pines," the singer used stylistic devices, such as voice breaks, slides, and the high falsetto vocal interlude, to accentuate the mournful and heartbroken sentiment of the text. While both recordings of this song show some emotional engagement with the lyrics, Monroe makes much clearer stylistic choices in his performance, especially in the third verse, where he makes extra use of vocal breaks to imitate the sound of weeping.

The level of drama in the interpretations of Loveless and Vincent's recordings is not significantly different from that of their male counterparts' recordings. Again, this is likely because the lyrics of these songs are simple with respect to drama; they do not offer much dramatic material to work with. It is between the two performances of "Pretty Polly" that there was the greatest difference of interpretation. Where Stanley only offers slight rhythmic variation between verses to suggest any dramatic development, Washburn brings the story to life by giving voice to the characters, using vibrato, voice breaks, and speech-like singing to bring out particularly dramatic moments. She also removes the element of sexual assault by choosing not to use the lyric "he opened up her bosom, white as any snow," which is gratuitous and violent. This performance choice, while subtle, can be interpreted as a protest of the indifference with which this explicit portrayal of violence against women is regarded. Her vocal interlude immediately follows the description of the murder, thus allowing the listener to reflect on that violence. While Polly's fate remains the same, Washburn restores some of her dignity, and sets and example for other performers who would handle similar material. 
While the study did show that the female performers took more creative liberties in their performances, the differences in emotional interpretation were not as significant as I predicted. This is partly because the lyrics of some of the songs selected did not present themes that require a particularly dramatic interpretation. Washburn's recording of Pretty Polly stands as the exception, and is an excellent example of the kind of "resistance" that Lydia Hamessley discusses in her research. ${ }^{131}$ Washburn sets an example of how female bluegrass performers can mindfully and proactively engage with these traditional songs without perpetuating the ambivalence towards the kind of violence portrayed in "Pretty Polly," as well as numerous other songs in the standard bluegrass repertoire. History has shown that music can be a powerful tool for social change, and musicians, bluegrass singers included, have a unique opportunity to address social issues, give voice to oppressed groups, and rearticulate and negotiate the position of those groups in American culture. ${ }^{132}$

This study also affirms that there is more than one style of singing that is considered "legitimate" within the bluegrass culture, further reinforced by the fact that all of the women discussed in this paper have been nominated for at least one IBMA Award, Rhonda Vincent claiming eight Female Vocalist of the Year awards. ${ }^{133}$ Following in the footsteps of all the women that Murphy Hicks Henry discusses in her book, these women, as well as many others who were not included in this study, have made and are continuing to make space for women in the bluegrass community to share their voices and change the definition of the bluegrass sound.

${ }^{131}$ Lydia Hamessley, "A Resisting Performance of an Appalachian Traditional Murder Ballad: Giving Voice to 'Pretty Polly," Women and Music: A Journal of Gender and Culture 9, no. 1 (2005): 33 .

${ }^{132}$ Luis Lemos, "Crossing Borders, Reshaping gender: Music and Gender in a Globalised World," e-cadernos CES, (2011):

133 "Recipient History," International Bluegrass Music Association, last modified 2016, https://ibma.org/awards/recipient-history. 
This study connects back to earlier research, discussed at the beginning of this paper. My study, which shows almost all artists frequently using the voice break technique in their performances, supports the research Brandon Paul and David Huron conducted in 2010, and extends their conclusions to bluegrass music. While the voice breaking technique was used in my study on grief-related words, especially by Bill Monroe on "In the Pines" and Abigail Washburn on "Pretty Polly," it was also used in songs with positive themes, such as Vincent's and Osborne's "Bluegrass Express" or Loveless's "Working on a Building." This further supports Paul and Huron's suggestion that the voice break technique is more broadly related to heightened emotion, not just expression of grief. ${ }^{134}$ This study also complements Tim Wise's work by showing the sustained influence of yodeling upon the bluegrass singing style, which came from the performance practices of early country singing. While the voice break is a subtler effect, it still relies on the same technique and serves a similar purpose. Therefore, this study shows that there is a case for further research on the yodeling practices found in bluegrass music.

This study also challenges the notion of the four-category singing style classification presented in Fred Bartenstein's paper on bluegrass singing and reveals a need for a more developed definition of the bluegrass singing style. While Vincent and Loveless both perform in their recordings with a belt-like vocal, each uses "subtle shadings and ornamentation," ${ }^{135}$ in their singing to convey meaning in their performances, something Bartenstein only attributes to Crooners. In order to understand how performances differ between the styles, a clearer explanation of what "subtle shadings" are would be needed. Furthermore, with the influence of

\footnotetext{
${ }^{134}$ David Huron and Brandon Paul, "An Association between Breaking Voice and Grief-related Lyrics in Country Music," Empirical Musicology Review 5, (2010): 31. EBSCOhost (201006380).

${ }^{135}$ Fred Bartenstein, "Bluegrass Vocals," (working paper, Bartenstein and Bluegrass, Yellow Springs, 2010), http://www.fredbartenstein.com/bgvocals.html.
} 
globalization and the resultantly increased communication between cultures, perhaps there is a need for a new category. Abigail Washburn is a great example of this, having traveled and performed bluegrass many times in China.. There are also thriving bluegrass communities in countries all over the world, with a particularly strong presence in Europe. ${ }^{136}$

There are several limitations to this study that could be explored in future research to shed more light in certain areas. Because my research was based on recordings, I had to infer, by listening for differences in timbre and using written references, where changes in register were occurring. Further acoustical analysis of live bluegrass singing of both male and female performers could more precisely define the differences in production and technique between the two genders when performing in the bluegrass vocal style. I also did not include contemporary male bluegrass singers or the early female bluegrass singers, such as those mentioned in Henry's text, for the sake of scope. Additionally, further comparisons between different demographics of bluegrass musicians might give a clearer understanding of what stylistic influences are a result of differences in generation, gender, and even geographical location.

Overall, this research serves to continue to shed light on the distinctly masculine origins of bluegrass performance and how the characteristics of male singing are coded into the bluegrass vocal style. Furthermore, this study shows how women have been changing the performance practice and shaping a new, broader understanding of what bluegrass singing can sound like. The charm and appeal of this genre is deeply rooted in its musical and historical heritage, which has been passed down and protected through generations. However, performers can still honor the traditions of the genre while exploring new ways of engaging with the music.

\footnotetext{
${ }^{136}$ Ruth Ellen Gruber, "Bluegrass Thrives Far From Home," The New York Times, April 9, 2009, http://www.nytimes.com/2009/04/10/arts/10iht-gruber.html.
} 
As Patricia Fagan explains in her discussion of Plato's Sirens, "Tradition is an institution that provides the possibility of a future that is continuous with the past and the present- that is an organic living movement ahead." ${ }^{, 137}$ Fagan acknowledges the truth of existence, to which we are all bound: in order to move forward in time, one must always change. This also applies to the bluegrass tradition, and my hope is that it grows to further include female voices and experiences in the bluegrass repertoire and community.

${ }^{137}$ Patricia Fagan, Plato and Tradition: The Poetic and Cultural Context of Philosophy (Evanston: Northwestern University Press, 2013), 57. 


\section{BIBLIOGRAPHY}

Artis, Bob. Bluegrass: From the Lonesome Wail of a Mountain Love Song to the Hammering Drive of the Scruggs-Style Banjo, the Story of an American Musical Tradition. New York: Hawthorn Books, 1975.

Bartenstein, Fred. "Bluegrass Generations.” Bartenstein and Bluegrass. 2014.

http://www.fredbartenstein.com/bluegen.html.

Bartenstein, Fred. "Bluegrass Vocals." (working paper, Bartenstein and Bluegrass, Yellow Springs, 2010). http://www.fredbartenstein.com/bgvocals.html.

"Bibliography." Della Mae. Accessed October 22, 2016. http://dellamae.com/celia-woodsmith.

Brady, Erika. "Contested Origins: Arnold Schultz and the Music of Western Kentucky." In Hidden in the Mix: The African American Presence in Country Music, edited by Diane Pecknold. Durham: Duke University Press, 2013.

Bufwack, Mary A. and Robert K. Oermann. Finding Her Voice: The Saga of Women in Country Music. New York: Crown Publishers, 1993.

Cantwell, Robert. Bluegrass Breakdown: The Making of the Old Southern Sound. Chicago: University of Illinois Press, 2003.

Collier, William G., and Timothy L. Hubbard. "Musical Scales and Evaluations of Happiness and Awkwardness: Effects of Pitch, Direction, and Scale Mode." The American Journal of Psychology 114, no. 3 (2001): 355-75.

Davids, Julia and Stephen LaTour. Vocal Technique: A Guide for Conductors, Teachers, and Singers. Long Grove: Waveland Press, 2012.

Encyclopedia of Appalachia, s.v. "Ballads," accessed October 22, 2016, http://www.encyclopediaofappalachia.com/entry.php?rec=31.

Fagan, Patricia. Plato and Tradition: The Poetic and Cultural Context of Philosophy. Evanston: Northwestern University Press, 2013.

Gruber, Ruth Ellen. "Bluegrass Thrives Far From Home.” The New York Times. April 9, 2009. http://www.nytimes.com/2009/04/10/arts/10iht-gruber.html

Hamessley, Lydia. "A Resisting Performance of an Appachian Traditional Murder Ballad: Giving Voice to 'Pretty Polly'.' Women and Music: A Journal of Gender and Culture 9, no. 1 (2005).

Hardwig, Bill. "Cocks, Balls, Bats, and Banjos: Masculinity and Competition in the Bluegrass Music of Bill Monroe." The Southern Quarterly 39, no. 4 (Summer 2001): 35-48. 
Henry, Casey. "Women in Bluegrass." The Murphy Method. 2016.

https://www.murphymethod.com/index.cfm?event=pages.content\&contentId=32.

Hicks Henry, Murphy. Pretty Good for a Girl: Women in Bluegrass. Urbana: University of Illinois Press, 2013.

Hicks Henry, Murphy. "Sally Ann Forrester.” In Pretty Good for a Girl: Women in Bluegrass, 13-19. Urbana: University of Illinois Press, 2013.

Huey, Steve. "Patty Loveless: Biography." Allmusic. Accessed October 22, 2016. http://www.allmusic.com/artist/patty-loveless-mn0000019241/biography.

Huron, David. "A Comparison of Average Pitch Height and Interval Size in Major- and Minor-key Themes: Evidence Consistent with Affect-related Pitch Prosody. "Empirical Musicology Review 5, no. 2 (2008): 59-63.

Huron, David and Brandon Paul. "An Association between Breaking Voice and Grief-related Lyrics in Country Music." Empirical Musicology Review 5 (2010): 27-35. EBSCOhost (2010-06380).

Jeffries, David. “Abigail Washburn: Biography.” Allmusic. Accessed October 22, 2016. http://www.allmusic.com/artist/abigail-washburn-mn0000776618/biography.

Johnson, Zac. "Rhonda Vincent: Biography." Allmusic. Accessed October 22, 2016. http://www.allmusic.com/artist/rhonda-vincent-mn0000472735/biography.

Kempfer, Brittny. "Contemporary Commercial Music Pedagogy: Selective Exercises for Developing Healthy Technique in Adolescent Singers." Master's thesis, The University of Wisconsin, Milwaukee. 2014.

Malone, Bill C. and Jocelyn R. Neal, Country Music, U.S.A. Austin: University of Texas Press, 2013.

McCusker, Kristine M., and Diane Pecknold. A Boy Named Sue: Gender and Country Music. Jackson: University Press of Mississippi, 2004.

McWhorter, John. "The 'Ax' Versus 'Ask' Question." Los Angeles Times, January 19, 2014. http://articles.latimes.com/2014/jan/19/opinion/la-oe-mcwhorter-black-speech-ax-20140119.

Neal, Jocelyn R. The Songs of Jimmie Rodgers: A Legacy in Country Music. Bloomington: Indiana University Press, 2009.

"Nirvana: MTV Unplugged in New York." Discogs. Accessed October 29, 2016. https://www.discogs.com/Nirvana-MTV-Unplugged-In-New-York/release/375980. 
Olsen, Ted and Charles K. Wolfe. The Bristol Sessions: Writing About the Big Bang of Country Music. Jefferson: McFarland, 2005.

"Patty Loveless Plans Mountain Soul II for September Release." CMT News. July, 2009.

http://www.cmt.com/news/1615536/patty-loveless-plans-mountain-soul-ii-for-septemberrelease/.

Price, Steven D. Old as the Hills: The Story of Bluegrass Music. New York: Viking Press, 1975.

Reid, Gary B. The Music of the Stanley Brothers. Urbana: University of Illinois Press, 2015.

“Recipient History.” International Bluegrass Music Association. Last modified 2016. https://ibma.org/awards/recipient-history.

Rosenberg, Neil. Bluegrass: A History. Urbana: University of Illinois Press, 2005

Rosenberg, Neil V. and Charles K. Wolfe. The Music of Bill Monroe. Urbana: University of Illinois Press, 2007.

Slade, Paul. Unprepared to Die: America's Greatest Murder Ballads and The True Crime Stories That Inspired Them. London: Soundcheck Books, 2015.

Smith, L. Mayne. “An Introduction to Bluegrass. Journal of American Folklore 78 (1965): 245-256.

Smith, Mayne. "An Informal Autobiography." MayneSmith.com. 2008. http://www.maynesmith.com/bio-disco-bibliography.htm.

Smith, Richard D. Can't You Hear Me Callin': The Life of Bill Monroe, Father of Bluegrass. Boston: Little, Brown and Co, 2000.

Stimeling, Travis D. "Taylor Swift's 'Pitch Problem' and the Place of Adolescent Girls in Country Music." In Country Boys and Redneck Women: New Essays in Gender and Country Music. Edited by Diane Pecknold and Kristine M. McCusker. Jackson : University Press of Mississippi. 2016.

Stimeling, Travis D. The Country Music Reader. New York: Oxford University Press, 2014.

Sullivan, James. "'O Brother' Inspires Bluegrass Boom / T Bone Burnett's Old-Timey Soundtrack Album a Surprise Hit." SFGate. March 7, 2002. http://www.sfgate.com/entertainment/article/O-Brotherinspires-bluegrass-boom-T-Bone-2866744.php.

Sweet, Stephen. "Bluegrass Music and its Misguided Representation of Appalachia." Popular Music \& Society 20 (1996): 37-51.

Vander Wel, Stephanie. "'I Am a Honky-Tonk Girl': Country Music, Gender, and Migration." Doctoral dissertation, University of California, Los Angeles, 2008. 
Washburn, Abigail. Abigail Washburn: Building US-China Relations...By Banjo. Video, 6:34. February 2012.

https://www.ted.com/talks/abigail washburn building us china relations by banjo/transcript? anguage $=$ en

Weisbard, Eric. “A Simple Song that Lives Beyond Time.” The New York Times. November 13, 1944. http://www.nytimes.com/1994/11/13/arts/pop-music-a-simple-song-that-lives-beyondtime.html?pagewanted=1.

Weissman, Dick. Which Side Are You On?: An Inside History of the Folk Music Revival in America. New York: Continuum, 2005.

Wise, Timothy E. Yodeling and Meaning in American Music (American Made Music Series). Jackson: University Press of Mississippi, 2016. Kindle Edition. 